\title{
BEYAZ ENERJİ HAKKI
}

\author{
The Right to White Energy
}

\section{Güven SÜSL ̈̈*}

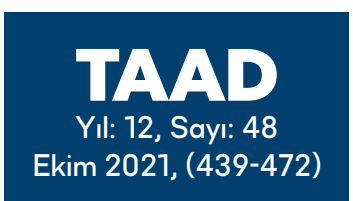

$\underline{\text { Makale Bilgisi }}$

Geliş Tarihi : 23.06.2021

Kabul Tarihi : 14.09.2021

Makale Türü: Araştırma

\section{$\underline{\text { Article Info }}$}

Received Date: 23.06.2021

Accepted Date: 14.09.2021

Article Type : Research

\begin{abstract}
ÖZET
Enerjinin çevre ile ilişkisi gün geçtikte daha yakından anlaşılmaktadır. Çevrenin enerji faaliyetlerinden etkilenmesi karşısında çevreyi kirletmeyen enerjiye yönelmek kaçınılmaz hale gelmiştir. Keza çevresel etkilerin sınır ve zaman tanımazlığı durumun önemini daha da artırmaktadır. Ancak yenilenebilir enerji kavramı ile temiz enerji kavramı ayn etmemektedir. Bu anlam farklılığı, temiz olmayı esas alan yeni bir kavramı gerektirmektedir. $\mathrm{Bu}$ doğrultuda çalışmamızda öncelikle yenilenebilir enerji ve temiz enerji kavram ayrımına değinilecektir. Yenilenebilir enerji, enerji kaynağının tükenmemesi ölçütünü temel almaktadır. Beyaz enerji ise enerjinin temizliğini, yani çevresel etkilerini esas almaktadır. Beyaz enerjinin bir hak olup olmadığının da belirlenmesi gerekmektedir. Beyaz enerji hakkı önce anayasal boyutta değerlendirilecektir. Bu konuda mahkeme kararları ile yargı organlarının yaklaşımı ele alınacaktır. Akabinde beyaz enerjinin yasal boyutu irdelenecek, bu hakkın içeriği ortaya konulacak ve son olarak da başka ülke uygulamalarından örnekler verilecektir.
\end{abstract}

Anahtar Kelimeler: Beyaz, Enerji, Çevre, Yeşil, Yenilenebilir, Hak

\begin{abstract}
The relationship between energy and the environment is understood more and more every day. In the face of the environment being affected by energy activities, it has become inevitable to turn to energy that does not pollute the environment. Likewise, the fact that environmental effects know no boundaries and time increases the importance of the situation even more. However, the concept of renewable energy and the concept of clean energy do not mean the same thing. This difference in meaning requires a new concept based on being clean. In this direction, in our study, first of all, the distinction between renewable energy and clean energy will be discussed. Renewable energy is based on the criterion of not running out of energy source. White energy, on the other hand, is based on the cleanliness of energy, that is, its environmental effects. It is also necessary to determine whether white energy is a right or not. The right to white energy will first be evaluated on a constitutional level. In this regard, the approach of court decisions and judicial bodies will be discussed. Then, the legal dimension of white energy will be examined, the content of this right will be revealed, and finally, examples from other countries will be given.
\end{abstract}

Keywords: White, Energy, Environment, Green, Renewable, Right

Bu makale Etik Kurul İznine tabi değildir.

* Öğr. Gör., Yaşar Üniversitesi Adalet Meslek Yüksekokulu, guven.suslu@yasar.edu.tr, https:// orcid.org/0000-0002-3628-9032. 


\section{GíRIŞ}

Çevre üzerinde giderek artan şekilde ortaya çıkan olumsuz etkilerde enerji faaliyetleri büyük paya sahiptir. Bu durum, ülkeleri çevreye daha duyarlı enerji kaynakları kullanımına doğru itmektedir. Öte yandan çevre sorunları çoğu zaman zaman ve mekândan bağımsız nitelik taşımaktadır. Oluşan çevre sorunlarının uluslararası boyutlu oluşu, ülkelerin bu konuda ortak hareket etmesinin de zeminini oluşturmaktadır. Çevrenin serbest ve bedava bir mal olmadığının algılanışı, oluşan maliyetin karşılanmasına ilişkin çözüm arayışlarını gündeme getirmiştir.

Çevre üzerinde oluşan olumsuz etkilere karşı enerji alanında akla ilk gelen ve popüler olan kavram yenilenebilir enerji kavramıdır. Hatta bu ilişki yenilenebilir enerji kavramının yeşil enerji olarak da adlandırılmasına ve hatta bu iki kavramın eş anlamlı olarak kullanılmasına kadar varmıştır.

Geleneksel olarak yenilenebilir ya da yeşil enerji denilince akla, tükenmeyen enerji kaynakları gelse de kavram aynı zamanda çevresel kaygıları da giderme izleri taşımaktadır. Ancak yenilenebilirlik ve temiz olma özellikleri birbirinden farklıdır. Bir enerji kaynağının temiz olması ile yenilenebilir olması birbirinden farklı kavramlardır. Yenilenebilir olma enerji kaynağının temiz olmasının ön şartı değildir. Yenilenebilirlik enerji kaynağının tükenmezliğini esas alırken temiz olmak ise enerjinin çevresel etkilerini esas almaktadır. Öte yandan her yenilenebilir enerji kaynağının temiz olduğunu iddia etmek de mümkün değildir.

Çalı̧̧mamızda bu kavram kullanımlarının irdelemesi yapılarak çevre üzerindeki etkileri temel alan bir kavram olarak beyaz enerji tercih edilmiştir. $\mathrm{Bu}$ kavram temelinde ise beyaz enerjinin bir hak konusu olup olmadığ 1 , bunun anayasal ve yasal temelleri değerlendirilecek, uluslararası alanda hukuki durum ele alınacak, konu ile ilgili özellikle Yüksek Mahkeme kararları temelinde yargı organlarının tutumu da incelenecektir. Beyaz enerji hakkının somutlaştırılması gereği nazara alınarak bu hakkın içeriğinin hangi yetkileri içerdiği de ortaya konulacaktır.

\section{BEYAZ ENERJII KAVRAMI}

Dünya genelinde ve ülkemizde her ne kadar yeşil enerji, enerjinin temiz olması ölçütünü temel almış ise de yerleşmiş ve özensiz kavram kullanımı yeşil enerji ile yenilenebilir enerji arasında bir anlam kardeşliği doğurmuştur. $\mathrm{Bu}$ özensiz kullanım o derece yaygınlaşmışıิı ki artık temiz enerji kavramı için yeşil enerji teriminin kullanılması, kullananın amacının tam olarak anlaşılmamasına, bu terimle temiz enerjiyi mi yoksa yenilenebilir enerjiyi mi kastettiği konusunda tereddütler doğmasına yol açmaktadır. Yeşil enerji ile beyaz enerji kavramlarının aynı şeyi ifade etmediği, beyaz enerji kavramının, 
enerji kaynağının yenilenebilirliğinden bağımsız olarak enerji kaynağının temiz olup olmadığını esas aldığı ifade edilmelidir. Yeşil enerji ve yenilenebilir enerji arasında yaratılan yanlış birliktelik, bir enerjinin çevreye zarar vermemesinin yani temiz olmasının ön koşulu olarak tükenmez olmasının gerektiği gibi bir anlamın çıkmasına yol açmaktadır. Oysa bir enerjinin yenilenebilirliği, o enerjinin temiz olmasına bir karine olmadığ gibi, bir enerjinin temiz olması için de o enerjinin yenilenebilirliği koşul değildir. Bu bağlamda çevreye zarar vermeme yani temiz olma ile yenilenebilirliği birbirinden ayırmak ve sadece temiz enerjiyi vurgulamak, onu anlatmak için, enerjinin yenilenebilirliğinden bağımsız, yeni bir kavram yaratmak gerekmektedir. İşte bu kavram beyaz enerji kavramıdır. Beyaz enerji kavramı böylece bir enerjinin yenilenebilir olma özelliğinden bağımsız olarak temiz olma niteliğini esas almaktadır. Kısacası beyaz enerji, temiz enerjiyi ifade etmektedir.

Beyaz enerji ile kastedilenin temiz enerji olduğu ifade edildiğine göre temiz enerjiden kastedilenin ne olduğunun belirlenmesi gerekmektedir. Temiz enerji kavramının doğrudan kullanıldığ 1 bir mevzuat hükmünün olup olmadığına bakmak gerekir. İsminde "Temiz Enerji”" kavramının yer aldığı bir kanun bulunmamaktadır. Yönetmeliklere bakılacak olursa "Temiz Enerji” kavramına adında yer veren yedi adet yönetmelik bulunmakta olup bu yönetmeliklerin tamamı, çeşitli üniversitelerin kendi bünyelerinde kurdukları temiz enerji uygulama ve araştırma merkezlerine ilişkindir. ${ }^{1}$ Yönetmeliklerde temiz enerji tanımlanmamıştır. $\mathrm{Bu}$ yönetmeliklerin dört tanesi, temiz ve yenilenebilirlik kavramlarını bir arada kullanmış, ${ }^{2}$ üç yönetmelik ise sadece temiz enerji kavramına yer vermiştir. ${ }^{3}$

Beyaz ya da temiz enerji kavramlarına ilişkin mevzuatta tanım bulunmamaktadır. Ancak "yenilenebilir enerji” kavramının mevzuatta yeri olduğu bilinmektedir. Gerçekten 5346 sayılı Yenilenebilir Enerji Kaynaklarının

1 Bu üniversitelerimiz; Düzce Üniversitesi, Niğde Ömer Halisdemir Üniversitesi, Selçuk Üniversitesi, Ondokuz Mayıs Üniversitesi, Gazi Üniversitesi, Muğla Sitkı Koçman Üniversitesi ve Hacettepe Üniversitesidir.

2 Düzce Üniversitesi Temiz Enerji Kaynakları Uygulama ve Araştırma Merkezi Yönetmeliği, 21.09.2014 tarih ve 29126 sayılı R.G., Niğde Üniversitesi Prof. Dr. Turhan Nejat Veziroğlu Temiz Enerji Uygulama ve Araştırma Merkezi Yönetmeliği, 28.02.2014 tarih ve 28927 (Mük) sayılı R.G., Selçuk Üniversitesi Yenilenebilir ve Temiz Enerji Uygulama ve Araştırma Merkezi Yönetmeliği, 24.06.2013 tarih ve 28687 sayılı R.G., Ondokuz Mayıs Üniversitesi Temiz Enerji Teknolojileri Uygulama ve Araştırma Merkezi Yönetmeliği, 08.12.2009 tarih ve 27426 sayılı R.G.

3 Gazi Üniversitesi Temiz Enerji Araştırma ve Uygulama Merkezi Yönetmeliği, 06.04.2005 tarih ve 25778 sayılı R.G., Muğla Sttk1 Koçman Üniversitesi Temiz Enerji Kaynakları Araştırma ve Uygulama Merkezi Yönetmeliği, 12.04.1996 tarih ve 22609 sayılı R.G., Hacettepe Üniversitesi Yeni ve Temiz Enerji Uygulama ve Araştırma Merkezi Yönetmeliği, 23.09.1993 tarih ve 21707 sayılı R.G. 
IIIIIIIIII!

Elektrik Enerjisi Üretimi Amaçlı Kullanımına İlişkin Kanun’un ${ }^{3}$. maddesinde yenilenebilir enerji kaynaklarının tanımına yer verilmiş ve hidrolik, rüzgâr, güneş, jeotermal, biokütle, biokütleden elde edilen gaz (çöp gazı dâhil), dalga, akıntı enerjisi ve gel-git gibi fosil olmayan enerji kaynakları olarak tanımlanmıştır. Görüldüğü üzere yenilenebilir enerji, temiz olmaktan ziyade sona ermeme, bitmeme ölçütünü esas almıştır. ${ }^{5}$ Ancak 5346 sayılı kanunun 1. maddesi, kanunun amaçları arasında çevrenin korunmasını da saydığından yenilenebilir enerjinin hiç değilse amaçları arasında çevrenin korunmasının da bulunduğu ifade edilmelidir.

Beyaz enerji kavramının anlamının ortaya koymada lafzi yorumdan hareket etmek gerekirse kirletmeyen, kirlilik yaratmayan enerji sonucuna varılmaktadır. Kirlilik kavramı ise OECD tarafından "insan sağlığını tehlikeye düşürme ile canlı varlıkları ve ekosistemleri hasara uğratabilme şeklinde zararlı sonuçlar doğuran ve çevrenin güzelliklerini ve diğer meşru kullanımlarını bozan veya bunlara mani olan maddelerin ya da enerjinin insanlar tarafindan ya da dolayli olarak çevreye intikali" ş̧eklinde tanımlanmıştır. ${ }^{6}$ Tanımda da görüleceği üzere kirlilik çevre ile yakın ilişkili olarak ortaya konulmuş ve özünde madde ya da enerjinin çevreye intikalinin kirliliğe yol açacağ ifade edilmiştir. $O$ halde beyaz enerji ile kastedilenin çevreyi kirletmeyen enerji olduğu söylenebilir.

\section{BEYAZ ENERJİ HAKKI}

2015 yılında yapılan Birleşmiş Milletler Sürdürülebilir Kalkınma Konferansında alınan 70/1 sayılı karar ile on yedi adet sürdürülebilir kalkınma amacı belirlemiştir. $\mathrm{Bu}$ amaçlardan yedincisi "herkes için uygun fiyatlı, güvenilir, sürdürülebilir ve modern enerjiye erişimin sağlanmasıdır."

Anılan yedi nolu amacı sağlamak için beş tane alt amaç belirlenmiş ve yedi nolu amacın gerçekleştirilmesi aşamalandırılmıştır. Bu alt amaçlar arasında çalışmamız için önemi haiz olanlar;

- 2030 yılı itibari ile uygun fiyatl1, modern ve güvenilir enerji hizmetlerine evrensel erişimi sağlamak

- 2030 yılı itibari ile küresel enerjide yenilenebilir enerjinin payını önemli ölçüde artırmak

- 2030 yılına kadar yenilenebilir enerji, enerji verimliliğini ve gelişmiş ve çevreye daha duyarlı fosil yakıt teknolojisini içeren çevreye duyarlı enerji

4 Yenilenebilir Enerji Kaynaklarının Elektrik Enerjisi Üretimi Amaçlı Kullanımına İlişkin Kanun, Kanun Numaras1: 5346, Kabul Tarihi:10.05.2005, RG 18.05.2005/25819

5 Yenilenebilir enerji üretirken de çevreye zarar verilmemesi gerektiği, yenilenebilirlik ise çevre dostu olmanın farklı anlamlara geldiği yolundaki düşünce için bkz. Münci Çakmak, İdare Hukuku Açısından Yenilenebilir Enerji, (Birinci Baskı, Seçkin Yayıncılık, 2018) 137-138

6 Nükhet Turgut, Çevre Hukuku, (Birinci Bask1, Savaş Yayınevi, 1998) 348 
araştırmaları ve teknolojilerine erişimi kolaylaştırmayı amaçlayan uluslararası iş birliğini geliştirmek ve enerji altyapısı ve temiz enerji teknolojilerine yapılan yatırmmları desteklemektir.?

Akabinde Birleşmiş Milletlerin 71/313 sayılı kararı ile Sürdürülebilir Kalkınma Amaçlarının gerçekleşip gerçekleşmediğini belirlemek üzere küresel göstergeler belirlenmiş ancak bu göstergelerin gelir seviyesi, coğrafi konum, yaş vb. sebeplerle ayrıştırılmasının mümkün olduğu da ifade edilmiştir. Yedi nolu sürdürülebilir kalkınma amacı olan herkes için uygun fiyatlı, güvenilir, sürdürülebilir ve modern enerjiye erişimin sağlanması amacının her bir alt amacı için kalkınma göstergelerinin tespiti de yapılmıştır. ${ }^{8}$ Bu kapsamda 70/1 sayılı BM kararı ile belirlenen yedi nolu amacın alt amaçları için belirlenen göstergeler şöyledir:

- 2030 yılı itibari ile uygun fiyatl, modern ve güvenilir enerji hizmetlerine evrensel erişimin sağlanmasının göstergesi olarak elektriğe erişen nüfus oranı ile isinma, aydinlatma ve yemek yapmada temiz yakıt ve temiz teknoloji kullanan nüfusun oranı belirlenmiştir.

- 2030 yılı itibari ile küresel enerjide yenilenebilir enerjinin payını önemli ölçüde artırmanın göstergesi olarak ise toplam enerji tüketiminde yenilenebilir enerjinin payı tespit edilmiştir.

- 2030 yılına kadar yenilenebilir enerji, enerji verimliliğini ve gelişmiş ve çevreye daha duyarlı fosil yakıt teknolojisini içeren çevreye duyarlı enerji araştırmaları ve teknolojilerine erişimi kolaylaştırmayı amaçlayan uluslararası işbirliğini geliştirmek ve enerji altyapısı ve temiz enerji teknolojilerine yapılan yatırımları desteklemenin göstergesi olarak da yenilenebilir enerji araştırmaları ve bu alandaki gelişmeyi ve hibrit sistemlerini de içeren yenilenebilir enerji üretimini desteklemek için gelişmekte olan ülkelere uluslararası yatırım akışı belirlenmiştir.

Görüleceği üzere modern ve çevreye duyarlı enerjiye erişim uluslararası metinlerin konusu olmaktadır. Enerjiye erişim hakkı unsurları itibari ile enerjiye erişimi, temel enerji hizmetlerini, uygun fiyatlı olmay1, güvenilir ve modern enerji hizmeti sunulmasını içermektedir.' Özellikle yukarıda bahsedilen alt amaçlar ve evrensel kalkınma göstergeleri dikkate alındığında yedi nolu amaç

Resolution Adopted By The General Assembly On 25 September 2015, Transforming Our World: The 2030 Agenda For Sustainable Development, (www.un.org) https://www.un.org/ en/development/desa/population/migration/generalassembly/docs/globalcompact/A_ RES_70_1_E.pdf Erişim Tarihi:22.03.2021

8 Resolution Adopted By The General Assembly On 6 July 2017, 71/313. Work Of The Statistical Commission Pertaining To The 2030 Agenda For Sustainable Development. (www.undocs.org), https://undocs.org/A/RES/71/313 Erişim Tarihi: 28.06.2021

9 Pınar Aksakal Aydın, İnsan Hakları Açısından Enerjiye Erişim Kavramı, (Birinci Baskı, Oniki Levha Yayıncılık, 2020) 109-114 
IIIIIIIIII

olan enerjiye erişim hakkının alt amaçlarından birisi "uygun fiyatlı, modern ve güvenilir enerji hizmetlerine evrensel erişimin sağlanması" olarak belirlenmiş, bu alt amacın gerçekleşme göstergesi olarak ise "temiz enerji ve temiz teknoloji kullanan nüfusun oranı" ortaya konulmuştur. Keza enerjiye erişim hakkının unsurları arasında yer alan modern enerji kavramının çevreye duyarlı enerji ve enerji teknolojileri alt amacı ile bağlantısı da dikkate alındığında enerjiye erişim hakkının beyaz enerji hakkını da içerdiği kanaatindeyiz.

1982 Anayasasında beyaz enerji ya da benzer anlamda temiz enerji hakkı adı ile ya da benzer anlama gelecek bir hakkın bulunmadığı görülmektedir. Dahası 1982 Anayasasında enerji kelimesi bile sadece 46/2. maddede kamulaştırma ile ilgili olarak bir kere yer bulmuştur. Dolayısıyla Anayasada ismen kendisine yer bulamasa da bu hakkın özü itibari ile Anayasada bulunup bulunmadığının ortaya konulması gerekir. Öncelikle enerjiye erişiminin ${ }^{10}$ bir hak olup olmadığına bakılacak olursa Türkiye'nin de taraf olduğu ve Anayasanın 90. maddesi gereği kanun hükmünde olan uluslararası belgelerde ${ }^{11}$ bu hakkın varlığının genel olarak yorum yolu ile çıkarıldı̆̆ı, iç hukukta yapılan düzenlemelerde ise mevzuatın enerjiye erişim hakkını sağlamaya çalıştı̆̆ 1 ancak özellikle serbest olan ve olmayan tüketici ayrımı ile gelir durumu düşük olan tüketiciler açısından bu hakkın korunamadığı ifade edilmiştir. ${ }^{12}$ BM tarafından yukarıda bahsedilen Genel Kurul kararları ise tavsiye niteliği taşımakta ve Devletler için hukuki bağlayıcılık taşımamaktadır. ${ }^{13}$

$\mathrm{Bu}$ noktada $\mathrm{AB}$ özelinde Topluluğun tamamında, istisnasız herkese makul fiyatlarla ve standart kalitede sunulan temel hizmet olarak tanımlanan "Evrensel Hizmet" kavramı da akla gelmektedir. Gerçi henüz iletişim ve posta hizmetlerinde uygulama aşamasında olsa da bu kavram yakın gelecekte enerjiyi de içine alan temel sektörlerde uygulanma imkanına kavuşacaktır. Evrensel hizmetin gelişiminde ise iki olasılık söz konusudur. İlk olasılıkta evrensel hizmet, hizmetin sunulmasinda zorluk olan durumlarda hizmetin

10 Enerjiye erişim bir hanenin hem çevreye duyarlı yemek pişirme olanaklarına (ilkel ya da modern anlamda yakıta ve kullanım teknolojilerine ulaşma) hem de temel enerji ihtiyaçlarını (telefon şarjı, radyo, birkaç ampül kullanımı gibi) gidermeye yetecek kadar elektriğe güvenilir ve uygun bedelle erişimi ve bunun zaman içerisinde bölgesel anlamda belirli bir ortalama seviyesine ulaşması olarak tanımlanmıştır. Energy Access Outlook 2017 From Poverty to Prosperity, (www.iea.org) https://iea.blob.core.windows.net/assets/9a67c2fcb605-4994-8eb5-29a0ac219499/WEO2017SpecialReport_EnergyAccessOutlook.pdf Erişim Tarihi: 28.06.2021

11 Bu belgeler arasında BM Şartı, İnsan Hakları Evrensel Bildirgesi, Medeni ve Siyasi Haklara İlişkin Uluslararası Sözleşme, Ekonomik, Sosyal ve Kültürel Haklara İlişkin Uluslararası Sözleşme sayılabilir. Aydın, (n 7) 60-76

12 ibid 94

13 Cem Sar, Birleşmiş Milletler Genel Kurul Kararlarının Hukuki Değeri, (1966) 21(4), AÜSBF Dergisi, 227, 241-242 
sunulma koşullarındaki güçlükten dolayı ya daha kötü kalitede sunulması ya da bu güçlükleri aşmanın maliyetinin tüketiciye yansitılması yolu ile diğer kullanıcılardan daha pahalı sunulmasıdır. İkinci olasılık ise hizmetin her koşulda herkese aynı kalitede sunulması ancak hizmetin daha maliyetli sunulduğu alanlardaki maliyetin herkese eşit olarak dağıtılmasıdır. Bu ikinci olasılık, başkasının hizmete erişmesindeki maliyeti bir başka tüketicinin üstlenmeye razı olup olmayacağı sorusunu akla getirmektedir. ${ }^{14}$ Örnek olarak dağlık bir alanda yaşayan bireye elektrik hizmetinin sunulması, şehir içinde yaşayan bireye nazaran daha maliyetlidir zira altyapının dağlık bölgede oluşturulması ve bu altyapıdan yararlanacak kişi sayısı dikkate alındığında maliyet artmaktadır. İşte bu maliyetin elektrik hizmetinden yararlanan herkese eşit olarak yansitılması ikinci olasılığın temel sorunudur.

Evrensel hizmetin ülkesel bir uygulama örneği olarak Fransa' da 18.03.1992 tarihinde kabul edilen "Kamu Hizmetleri Şartı'nda" kamu hizmetlerinin işleyiş ilkeleri arasında özellikle kırsal alanlar ve hassas bölgeler hedeflenerek coğrafi olarak yaygınlık ve ulaşılabilirlik de sayılmıştır. ${ }^{15}$

\section{A. Temiz Enerjinin Ayrı Bir Hak Olarak Kabulünün Gerekliliği}

Temiz Enerjinin bağımsız bir hak olarak kabulü, özellikle çevre hakkından bağımsız şekilde ele alınması, çevre hakkına yönelik bazı sınırlamalardan kurtulmasını sağlaması bakımından önem taşımaktadır. Herşeyden önce 2872 sayılı Çevre Kanunu 1. maddesinde Kanunun amacını, bütün canlıların ortak varlığ 1 olan çevrenin, sürdürülebilir çevre ve sürdürülebilir kalkınma ilkeleri doğrultusunda korunmasını sağlamak şeklinde ifade etmiş, 2. maddede ise Sürdürülebilir kalkınma, bugünkü ve gelecek kuşakların, sağlıklı bir çevrede yaşamasını güvence altına alan çevresel, ekonomik ve sosyal hedefler arasında denge kurulması esasına dayalı kalkınma ve gelişmeyi ifade etmektedir. Dolayısıyla çevre hakkı, sürdürülebilir kalkınma ilkeleri doğrultusunda tanınmış, sürdürülebilir kalkınma ise çevresel, ekonomik ve sosyal hedefler arasında bir denge kurulmasını esas almıştır. Sürdürülebilir kalkınma kavramı bu bağlamda çok boyutlu bir kavram olup, çevresel boyutlarının yanı sıra iktisadi ve sosyal boyutları da haizdir ve bu kavram hakkında yapılan tanımlamalar, hangi boyutun esas alındığına göre farklılaşmaktadır. ${ }^{16}$ Ekonomik hedeflerin çevresel hedeflerin önüne geçmesi ve çevresel ekonomi açgözlülügünün ${ }^{17}$ ortaya çıkması, çevre hakkını kâğıt üzerinde kalması sonucunu doğurabilecektir. Bu bağlamda temiz enerji hakkının bağımsızlığını

\footnotetext{
İl Han Özay, Günışığında Yönetim, (Üçüncü Bask1, Filiz Kitabevi, 2017) 274-275

Onur Karahanoğulları, Kamu Hizmeti, (Birinci Bask1, Turhan Kitabevi, 2015) 245-250

16 Onur Yeni, Sürdürülebilirlik Ve Sürdürülebilir Kalkınma: Bir Yazın Taramas1, (2014) 16(3),

Gazi Üniversitesi İktisadi ve İdari Bilimler Fakültesi Dergisi, 181, 185

17 Emin Memiş, Çevre ve Çevre İdare Hukuku, (İkinci Bask1, Filiz Kitabevi, 2015) 347.
} 
IIIIIIIIII!

kazanması, sürdürülebilir kalkınma ilkesinin yaratacağı bu tehlikenin hiç değilse temiz enerji hakkı özelinde etki yaratmamasını sağlayacaktır.

Belirtilmesi gereken bir diğer husus çevrenin kirletilmesine sadece temiz olmayan enerji kullanımının yol açmadığıdır. Çevrenin kirletilmesi çok daha geniş bir kavramdır ve bu noktada çevre hakkı ile temiz enerji hakkı arasında ayrım yapılması gerekir. Ayrıca temiz olmayan enerji kullanımının yaratacağı tek sonuç çevrenin kirletilmesi değildir ve başka pek çok sonuç doğurmaktadır. $\mathrm{Bu}$ bağlamda temiz enerji hakkının bağımsız bir hak olarak kabulü ve düzenleme altına alınması önem taşımaktadır. Her ne kadar bir hürriyetin var olması için anayasa ya da kanunla tanınmasına gerek olmasa da özellikle anayasal düzenleme yapılması, yasalarla bu özgürlüğün ihlal edilememesi sonucunu yaratacağından hürriyet daha da güvenceli hale gelecektir. ${ }^{18}$ Temiz enerji hakkının da anayasal statüye kavuşturulması, bu hakkın normlar hiyerarşisindeki yeri itibari ile ölçü norm olmasını sağlayarak bu norma aykırı yasal düzenleme yapılamaması söz konusu olacaktır.

\section{B. Türk Hukukunda Beyaz Enerji Hakkının Varlığı}

Hukukumuzda "Beyaz Enerji Hakkı" nın bulunup bulunmadığının anayasal ve yasal bağlamda ayrı ayrı incelenmesi gerekmektedir.

\section{Anayasal Bağlamda Beyaz Enerji}

Beyaz enerjinin anlamının saptanmasından sonra beyaz enerjinin bir hak olup olmadığ 1 ve başta anayasal ve ardından yasal dayanaklarının neler olduğu belirlenebilir. 1982 Anayasasında beyaz enerji ile ilgili hiçbir düzenleme yoktur. Enerjiye erişim hakkının yorum yolu ile çıkarıldığı uluslararası belgelere taraf olmamız sebebi ile bunların iç hukuka aktarılmış olmaları ve Anayasaya aykırılıklarının da ileri sürülemeyecek oluşu, enerjiye erişim hakkının beyaz enerji hakkını da içermesi sebebi ile dolaylı bir kanun üstü dayanak sayılabileceği düşünülmektedir. Ancak asıl dayanak yapılabilecek hüküm ise Anayasamızda yer alan çevre ile ilgili düzenlemedir. Gerçekten Anayasanın "Sağl1k hizmetleri ve çevrenin korunması" başlıklı 56. maddesinde "Herkes, sağlıklı ve dengeli bir çevrede yaşama hakkına sahiptir. Çevreyi geliştirmek, çevre sağlığını korumak ve çevre kirlenmesini önlemek Devletin ve vatandaşların ödevidir." hükmüne yer verilmiştir. Öncelikle düzenlemede hakkın sahibi olarak hiçbir ayrım yapılmaksızın herkes gösterilmişken, çevreyi koruma ödevini ise Devlete ve vatandaşlara ait olduğunun ifade edilmesi, bir çelişki arz etmektedir. Bu noktada çevreyi koruma ödevinin de tıpkı hakkın

18 Kemal Gözler, Yorum İlkeleri, Kamu Hukukçuları Platformu Anayasa Hukukunda Yorum ve Norm Somutlaşmas1, Türkiye Barolar Birliği, 29-30 Eylül 2012, (Birinci Bask1, TBB Yayınları, 2013) 82 
öznesinde olduğu gibi herkes olarak anlaşılması, amaçsal yorum yolu ile mümkündür ve elzemdir. ${ }^{19}$

1982 Anayasasının 56/1. madde hükmü temel hak ve özgürlüklere ilişkin anayasal normların önemli bir kısmı gibi soyut ve genel nitelik taşımaktadır. Soyut ve genel nitelikli anayasal normlar ise, temel hak ve özgürlüğe ilişkin ana güvenceyi belirtmek üzere ifade edilmekte fakat çoğu zaman ilgili hak ve özgürlüğün kapsamına o hak ve özgürlügün hangi kullanım biçimlerinin girdiğini ya da girmediğini belirtmemektedirler. Sonuç itibariyle hak ve özgürlüğün somutlaştırılmasında, yasa koyucuya ve uyuşmazlık halinde yargısal karara alan yaratılmaktadır. ${ }^{20} \mathrm{Bu}$ bağlamda 56/1. maddede düzenlenen temel hak ve özgürlüğü somutlaştırma noktasında yargı kararlarına bakmak gerekmektedir.

\section{a. Anayasa Mahkemesi Kararlarına Bakış}

Anayasa Mahkemesi, 3213 sayılı Maden Kanunu'nun ek 1. maddesinin 4. fikrası ile ilgili olarak Anayasa'nın 56. maddesine aykırılık iddiası ile ilgili olarak önüne gelen itiraz başvurusunda verdiği kararda ${ }^{21}$, Anayasa'da yer alan "sağlıklı ve dengeli çevre" kavramına, doğal güzelliklerin korunduğu, kentleşme ve sanayileşmenin getirdiği hava ve su kirlenmesinin önlendiği bir çevre kadar, işin niteliğine göre belirli esaslara uygun olarak madencilik faaliyetlerinin gerçekleştirildiği çevrenin de gireceği kuşkusuz olduğunu, sağliklı ve dengeli bir çevre yaratılmasının, öncelikle yapılacak madencilik faaliyetinin denetlenmesini gerektirdiğini vurgulamıştır. Mahkemenin bu kararı, çevre kavramına madencilik, dolayısıyla enerji temin faaliyetlerini sokması açısından büyük önem taşımaktadır. Görüldüğü üzere Anayasa Mahkemesi, çevre hakkının konusunu, sağlıklı ve dengeli bir çevrenin öğelerini genişletmek suretiyle geliştirmektedir. ${ }^{22}$

19 Ümit Güveyi, 1982 Anayasası Kapsamında Çevre Hakkının Karşılaştırmalı Kısa Bir Tahlili, (2018) 24(2), Marmara Üniversitesi Hukuk Fakültesi Hukuk Araştırmaları Dergisi, 633, 648

20 Bertil Emrah Oder, Anayasa Yargısında Temel Hak Ve Özgürlüklerin Yorumu: Düzenleme Biçimleri, Kanıtlama Ve Somutlaştırma Sorunları-2001 Anayasa Değişiklikleri Sonrasına İlişkin Gözlemler, Kamu Hukukçuları Platformu Anayasa Hukukunda Yorum Ve Norm Somutlaşmas1, 29-30 Eylül 2012, (Birinci Bask1, TBB Yayınları, 2013) 127

21 Anayasa Mahkemesi, 2011/110, 24.05.2012

22 Yasemin Semiz, 2016, Çevre Hakkı Kavramı ve Avrupa İnsan Hakları Mahkemesi’nin Çevre Hakkına Yaklaşımı, (Yayınlanmamış Yüksek Lisans Tezi), Galatasaray Üniversitesi Sosyal Bilimler Enstitüsü, İstanbul, 17. Mahkeme kararı ile bir hakkın varlığının saptanmasına güzel bir örnek olarak Hindistan Yüksek Mahkemesinin Attakoya Thangal v. Union of India kararı verilebilir. Mahkeme Anayasa'da açıkça su hakkının yer almadığı Hindistan'da Anayasa'da yer alan "yaşam hakkını" yorumlayarak su hakkının varlığını kabul etmiş ve idarenin kişilerin yaşadığı bölgenin yer altı sularından faydalanarak bir başka bölgenin su ihtiyacını karşılamasını "yaşam hakkının” ihlali olarak kabul etmiştir. Ayşenur Narin, Su Hakkı ve Bir Müdahale Aracı Olarak Suyun Özelleştirilmesi, (2016) 7(27), TAA Dergisi, 741 dn. 40 
IIIIIIIIIII-

5491 sayılı “Çevre Kanunu'nda Değişiklik Yapılmasına Dair Kanununun 7. maddesi ile 2872 sayılı Çevre Kanunu'nun 10/3. maddesinin de "Petrol, jeotermal kaynaklarve maden arama faaliyetleri, Çevresel Etki Değerlendirmesi kapsamı dışındadır. " hükmüne yer verilmiş̧tir. Anayasa Mahkemesi 5491 sayılı Kanunun çeşitli maddelerinin Anayasa'nın 2., 6., 7., 8., 11., 13., 17., 56., 63., 90. ve 168. maddelerine aykırılığı iddiası ile ilgili olarak açılan iptal davasında, ${ }^{23}$ Anayasa'nın 56. maddesinin birinci ve ikinci fikrasında "Herkes, sağlıklı ve dengeli bir çevrede yaşama hakkına sahiptir. Çevreyi geliştirmek, çevre sağlığını korumak ve çevre kirlenmesini önlemek Devletin ve vatandaşların ödevidir. " hükmünün yer aldığını, çevresel etki değerlendirmesi ile korunmaya çalışlan temel unsurun, çevre ve bu çevre içerisindeki varlıklar olduğunu, ÇED kapsamı dışında tutulan arama faaliyetlerinin, biyolojik çeşitlilik üzerinde ya da doğada değişiklikler meydana getirebileceğini, bu değişikliklerin uzun dönemli etkilerinin olabileceğini, bu nedenle çevre için riskler taşıdığını, iptali istenen kural kapsamındaki arama faaliyetinde, mevcut risklerin ortadan kaldırılabilmesi ve önlenebilmesi için ÇED'in öngörülmesinin, Anayasa'nın 56. maddesinde Devlete verilen çevrenin korunması yükümlülüğünün bir gereği olduğunu, anılan kuralla, petrol, jeotermal kaynaklar ve maden arama faaliyetlerinin çevresel etki değerlendirilmesi kapsamı dışında tutulmasının Anayasa'nın 56. maddesine aykırı olduğunu hüküm altına almıştır. Görüldüğü üzere Mahkeme bu kararında da enerji üretimine yönelik olan ve bu bağlamda çevre kapsamına dahil olan varlıklar üzerinde etkisi olabilecek faaliyetleri 56. madde kapsamında değerlendirerek genişletici yaklaşımını devam ettirmiştir.

Son olarak Mahkeme, 29.12.2010 günlü, 6094 sayılı Yenilenebilir Enerji Kaynaklarının Elektrik Enerjisi Üretimi Amaçlı Kullanımına İlişkin Kanunda Değişiklik Yapılmasına Dair Kanun'un bazı maddelerinin Anayasa'nın 2., 17., 56., 128. ve 166. maddelerine aykırılığı iddiası ile açılan iptal davasında verdiği kararda, ${ }^{24}$ yenilenebilir enerjinin, çevrenin korunmasındaki rolüne değinerek kömür, doğalgaz ve fuel-oil gibi fosil yakıtlarının kullanımı sonucu dünya yüzeyinin ortalama sıcaklığında meydana gelen artışa bağlı olarak uzun vadede iklim değişiklikleri, buzulların erimesi, mevsimlerin kayması ve tarım alanlarının verimsizleşmesi gibi sorunlara yol açabilecek nitelikteki sera gazı salınımının düşürülmesi amacıyla yenilenebilir enerji kaynaklarına öncelik verilmesinin, doğanın korunması bakımından büyük önem taşıdığını vurgulamıştır. Mahkemenin bu kararı da enerji üretim faaliyetlerinin, çevresel varlıklar üzerindeki etkisini ortaya koyarak, çevrenin korunmasında enerji kaynaklarının rolünü saptamış, çevre kavramının enerji ile olan yakın ilişkisini ortaya koymuştur.

24 Anayasa Mahkemesi, 2011/27, 05.07.2012 


\section{b. Avrupa İnsan Hakları Mahkemesi Kararlarına Bakış}

Konuya Avrupa İnsan Hakları Mahkemesi açısından bakılacak olursa, çevre hakkının, Avrupa İnsan Hakları Sözleşmesi'nde ya da Sözleşme'ye ek protokollerde bağımsız bir hak olarak düzenlenmediği ancak Avrupa İnsan Hakları Mahkemesi'nin, çevre hukukunun gelişimi ve çevresel sorunların artması sebebi ile vermiş olduğu kararlarla çevre hakkının gelişmesi ve çevrenin korunmasında Avrupa İnsan Hakları Sözleşmesi'nin önemli bir hukuki işlev kazanmasını sağladığı söylenmelidir. ${ }^{25}$ Bu noktada Mahkemenin, Sözleşmede yer alan bazı hakları çevre hakkı ile birlikte yorumlamak suretiyle çevrenin korunmasına katkıda bulunduğu görülmektedir. ${ }^{26}$ Mahkemenin bu yorumlarda en sık başvurduğu hak Sözleşmenin 8. maddesinde düzenlenen "Özel Hayat ve Aile Hayatının Korunması Hakkı" iken yine 2. maddede düzenlenen Yaşam Hakkı", 6. maddede düzenlenen "Adil Yargılanma Hakkı" da Mahkemenin çevre hakkının varlığını ile birlikte değerlendirdiği haklar arasında yer almaktadır. ${ }^{27}$ Avrupa İnsan Hakları Mahkemesi'ne yapılmış olan başvurular özellikle devlet ya da özel kişilerin tehlikeli faaliyetlerinden dolayı yaşam hakkının tehdit altında olması iddialarında yoğunlaşmaktadır ${ }^{28}$ Mahkeme, pozitif yükümlülük doktrini kapsamında Devletlere özellikle 8. madde kapsamında yükümlülükler yaratmakta ancak yeni hak kategorileri yaratmaya yanaşmamakta, Devletlerin pozitif yükümlülüğü konusunda ise özen ilkesi çerçevesinde hakkı koruyucu gerekli özenin gösterilip gösterilmediğini ölçüt yapmaktadır. Mahkeme yatay etki doktrini kapsamında 8. maddeyi bireyler arası yatay ilişkilerde de Devletin pozitif yükümlülüğü olduğu şeklinde yorumlamakta ve bireylerin başka bireylerden gelecek ihlallere karşı korunmasını da Devlete pozitif bir yükümlülük olarak yüklemektedir. ${ }^{29}$

Mahkemenin vermiş olduğu Okyay/Türkiye karar1 ${ }^{30}$ çevre hakkının bağımsız bir hak olarak kabulünün önemini ortaya koymasis ${ }^{31}$ ve Mahkemenin bu hakkı Avrupa İnsan Hakları Sözleşmesi 6. maddesi ile bağlantılı olarak

25 Erkan Duymaz, Avrupa İnsan Hakları Mahkemesi'nin Çevrenin Korunmasına Katkısı, (2012) 47, İstanbul Üniversitesi Siyasal Bilgiler Fakültesi Dergisi, 123

26 Alistar Mowbray, Cases and Materials on the European Convention on Human Rights, (2nd edn, Oxford University Press, 2007) 546-552

27 Bahar Konuk Sommer, Türk Hukukunda Çevre Hakkının Bireysel Başvuru Yoluyla Korunması, (2019) 4(2), Yıldırım Beyazıt Hukuk Fakültesi Dergisi, 169, 174-177

28 Duymaz, (n 23) 135

29 Dilara Yüzer Eltimur, AİHM ve Anayasa Mahkemesi İçtihatları Işı̆̆ında Çevrenin Korunmasında Devletin Pozitif Yükümlülükleri, (2018) 13(145), Terazi Hukuk Dergisi,93, 98-100

30 AİHM 36220/97, 12.07.2005

31 Ancak Mahkeme AİHS'nin hiçbir kuralında çevre hakkının yer almadığını kabul etmektedir. Bu konuda 22.05.2003 tarih ve 98/41666 başvuru nolu Kyrtatos v Yunanistan ve 09.06.2005 tarih ve 00/55723 başvuru nolu Fadeyeva v Rusya kararlarına bakılabilir. 
IIIIIIIIII

ele alması açısından değerlidir. Gerçekten davaya konu olan olayda konuyu AİHM önüne getiren, Yatağan, Yeniköy ve Gökova termik santrallerinin faaliyetlerinin durdurulması için İzmir'de yaşayan avukatlardır. Nükleer santrale 4-5 km mesafede yaşamasına rağmen başvuruları kabul edilmeyenlere nazaran termik santrallere $250 \mathrm{~km}$ uzaklıkta oturanların başvurularının kabul edilmesi çevre hakkının iç hukukta tanınmasının önemini ortaya koymaktadır. ${ }^{32}$ Davada başvurucular 1982 Anayasasının 56. maddesi uyarınca sağlıklı ve dengeli bir çevrede yaşamanın anayasal hakları olduğu tezine dayanmışlardır. ${ }^{33}$ Başvurucuların bu hakka değil de doğrudan yaşam hakkına dayanmaları halinde Mahkemenin daha önceki kararlarına da bakılınca başvurunun reddinin söz konusu olacağ 1 ifade edilmiştir. ${ }^{34}$

Anayasa Mahkemesinin, çevre hakkının bireysel başvuruya konu edilmesi noktasında yaklaşımının müspet olduğu belirtilmelidir. Ancak Mahkeme, çevre hakkının ihlaline ilişkin önüne gelen bireysel başvurularda değerlendirmelerini 56. madde kapsamında değil, Anayasanın 17. maddesinde düzenlenmiş olan "Maddi ve manevi varlığın korunması ve geliştirilmesi" hakkı, 20. maddede yer alan "Özel hayatın gizliliği", 21. maddede düzenlenen "Konut dokunulmazlığı" ve 22. maddede yer alan "Haberleşme hürriyeti" çerçevesinde yapmakta ve bu konuda değerlendirmeyi neden 17. madde çerçevesinde yaptığına da Mehmet Kurt başvurunda $^{35}$ verdiği kararda açıklık getirmektedir. Mahkeme,

32 Duymaz, (n 23) 138

33 Nilgün Tortop, İnsan Hakları Avrupa Mahkemesi Kararları, (2006), 62, TBB Dergisi, 449, 450

34 Duymaz, (n 23) 138-139 Öte yandan Mahkemeye göre santrallerin faaliyetlerinin durdurulmasına yönelik verilen yürütmenin durdurulması kararlarının idare tarafından uygulanmaması ve faaliyetlere devam edilmesine karar verilmesi yasal temelden yoksun ve iç hukuka göre açıkça hukuka aykırı olup bu durum yargı kararlarına karşı hile yapmakla aynı şeydir. Mahkeme, böyle bir durumun hukuki güvenlik ve hukukun üstünlüğüne dayalı hukuk devleti ilkesine aykırı olduğunu ifade ederek ulusal makamların iç hukukta verilen mahkeme kararlarını makul süre içinde ve hukuka uygun şekilde yerine getirmede ihmalleri olduğunu ve bu sebeple Sözleşmenin 6/1. maddesinin ihlal edildiğine hükmetmiştir. Tortop, (n 31) 466-467

35 Anayasa Mahkemesinin 25.02.2016 tarih ve 2013/2552 başvuru numaralı kararı. https:// kararlarbilgibankasi.anayasa.gov.tr/BB/2013/2552?Dil=tr Erişim Tarihi:24.07.2021, Anaysa Mahkemesi, Anayasanın 20. Maddesi kapsamında özel hayatın gizliliği ve aile hayatına saygı hakkı kapsamında yapılan bir bireysel başvuru kararında ise çevresel rahatsızlık iddialarının değerlendirilebilmesi için çevrenin genel olarak bozulması değil bireylerin özel veya aile hayatı ile konutları için zararlı bir etkinin söz konusu olması ve başvuruya konu işletmenin faaliyetlerinin başvurucuları güncel ve kişisel olarak doğrudan etkilediğinin başvurucular tarafından ortaya konulması gerektiğini vurgulayarak belirli bir bölgede yapılması planlanan maden işletmesi faaliyetlerinin başvurucuları güncel ve kişisel olarak doğrudan etkilediğinin başvurucular tarafından ortaya konulamadığının anlaşıldığını ve bu sebeple başvurucuların mağdur statüsünün bulunmadığı sonucuna 
Anayasa'da yer alan 'Herkes, Anayasada güvence altına alınmış temel hak ve özgürlüklerinden, Avrupa İnsan Hakları Sözleşmesi kapsamındaki herhangi birinin kamu gücü tarafından, ihlal edildiği iddiasıyla Anayasa Mahkemesine başvurabilir." hükmünün, Anayasa' da yer alan ikinci ve üçüncü kuşak hakların ihlal edildiği iddiasıyla bireysel başvuruda bulunulamayacağ yorumlanması gerektiğini belirtmektedir. ${ }^{36}$

\section{c. Danıştay Kararlarına Bakış}

Danıştay'ın yaklaşımına bakılacak olursa, 3218 sayılı Serbest Bölgeler Kanununun 2. ve 2942 sayılı Kamulaştırma Kanunun 27.maddelerine göre, ... Serbest Bölgesinin hudutlarının belirlenmesine, bu bölge dahilinde kalan özel mülkiyete ait taşınmazların acele kamulaştırılmasına, kamulaştırma işlemleriyle Maliye ve Gümrük Bakanlığı Milli Emlak Genel Müdürlüğünün görevlendirilmesine ve 89/14633 sayılı Kararnamenin yürürlükten kaldırılmasına ilişkin 7.5.1990 günlü ve 20511 sayılı Resmi Gazetede yayımlanan 90/380 sayılı Bakanlar Kurulu kararının iptali istemiyle açılan davada Danıştay, ${ }^{37}$ Türkiye Cumhuriyeti Anayasasıının 56.maddesinde; herkesin sağlıklı ve dengeli bir çevrede yaşama hakkına sahip bulunduğu,

ulaşıldığına hükmetmiştir. Anayasa Mahkemesinin 08.05.2019 tarih ve 2015/19256 başvuru numaralı Adnan Ayan vd. kararı https://kararlarbilgibankasi.anayasa.gov.tr/ BB/2015/19256?KelimeAra\%5B0\%5D=2872+\&page=2 Erişim Tarihi: 24.07.2021

36 Sommer, (n 25) 180-181. Anayasa Mahkemesi Demirdöven Köyü Tüzel Kişiliği ve diğerleri bireysel başvurusu ile ilgili kararında ÇED olumlu kararı verildikten sonra yöre halkına yapılacak bilgilendirmenin halkın haberdar olmasını sağlayacak şekilde yapılması gerektiğini, başvuruya konu olayda ÇED olumlu kararının Valilik ilan panosuna asılması ile yetinildiğinin tespit edildiğini, panoya asma yöntemi dışında köyde yaşayan yöre halkının konudan haberdar olmasını sağlayacak başkaca herhangi bir yönteme başvurulduğuna ya da başvurucuların karardan bir şekilde haberdar olduklarının kabulünü haklı kılan bir neden bulunduğuna dair herhangi bir bilgi ya da belgenin bulunmadığını, köyde yaşayan başvurucuların şehir merkezinde bulunan Valilik ilan panosunda yayınlanan kararı takip ederek ilan tarihinden itibaren dava açmalarını beklemenin hukuki güvenlik ve belirlilik ilkeleri bağlamında öngörülebilirlik sınırları içinde olmadığı kanaatine varıldığını, dava açma süresinin, başvurucuların henüz dava hakkının doğduğundan haberdar olmadığı bir dönemde işletilmeye başlamasının, mahkemeye erişim hakkına yapılan müdahaleyi ölçüsüz kıldığını, bu çerçevede İdare Mahkemesinin ÇED kararının öğrenilmesine ve değerlendirilmesine imkân tanımayan nitelikteki Valilik ilan tarihini esas alarak dava açma sürelerini belirlemesine ilişkin yorumunun başvurucuların mahkemeye erişim hakkına yönelik katı bir yorum olduğunu ve bu yorumun başvurucuların mahkemeye erişim hakkını kullanmasını aşırı derecede güçleştirdiğinin tespit edildiğini, açıklanan gerekçelerle başvurucu gerçek kişilerin Anayasa'nın 36. maddesinde güvence altına alınan adil yargılanma hakkı kapsamındaki mahkemeye erişim hakkının ihlal edildiğine karar vermiştir. Anayasa Mahkemesinin 25.12.2018 tarih ve 2014/14359 başvuru numaralı kararı. 25.12.2018. https://kararlarbilgibankasi.anayasa.gov.tr/ BB/2014/14359?KelimeAra\%5B\%5D=demird\%C3\%B6ven Erişim Tarihi: 24.07.2021 
çevreyi geliştirmenin, çevre sağlığını korumak ve çevre kirlenmesini önlemenin Devletin ve vatandaşların ödevi olduğu hükmüne yer verildiğini, toplumun bütün bireyleri yanında, kamu hizmetini yürüten idarelere de, çevre sağlığını koruma yükümlülüğü getirildiği tespit etmiştir. Danıştay, dava kapsamında, Yüksek Planlama Kurulu tarafından alınan karar ile İzmir-Aliağa Serbest Bölgesinde yürütülecek faaliyetlerin belirtildiğini ve Bölgede, sadece bu kararda belirtilen konularda faaliyette bulunulmasına izin verileceğinin bildirildiğini, Yüksek Planlama Kurulunun söz konusu kararında, uyuşmazlık konusu serbest bölgedeki faaliyet konuları üretim faaliyetleri ile ticaret ve hizmet faaliyetleri şeklinde düzenlenerek üretim faaliyetlerinin de «imalat sanayi sektöründe yer alan faaliyetler, özellikle gida ve yem gibi tarım ve gübre, boya, deterjan ve diğer kimya, petro kimya ve kömür ürünlerinin sağlanmas1, konserve, kazan, tank ve boru üretimi gibi çeşitli çelik işletmelerinin kurulmaları ve bunlar için gerekli enerji üretim faaliyetleri, klima ve deniz araçları imalatı, tekstil ve beton ürünleri, optik ve tıbbi elektronik alet, bilgisayar ve benzeri alet ve ekipmanların üretimi ile ihracata katkısı olan her türlü tarım ve sanayi maddelerinin üretim faaliyetleri» şeklinde belirlendiğini, Yüksek Planlama Kurulu kararıyla faaliyet konuları belirlenen sınai yatırımların İzmir-Aliağa Serbest Bölgesinde gerçekleşmesi halinde 2872 sayılı Çevre Kanunu hükümleri dikkate alınarak ekolojik dengenin bozulup bozulmayacağı konusunda bir araştırma yapılıp yapılmadığının davalı idareden sorulduğunu, verilen cevaptan bu hususta herhangi bir inceleme yapılmadığının anlaşıldığını, serbest bölge olarak belirlenen yerde Yüksek Planlama Kurulunca kabul edilen üretim faaliyetleriyle ticaret ve hizmet faaliyetlerinin yürütülmeye başlanılmasında kamu yararının davalı idarece ortaya konulmaması karşısında belirtilen hususun saptanması zorunluluğunun ortaya çıktığını, kamu yararı kavramıyla belirlenmek istenilenin, kurulan serbest bölgede ekolojik dengenin bozulup bozulmayacağının, doğanın kirletilip kirletilmeyeceğinin, arazinin ve doğal kaynakların, su, toprak ve havanın, ülkenin bitki ve hayvan varlığının, doğal ve tarihsel zenginliklerinin zedelenip zedelenmeyeceğinin saptanması ve ileride yapılacak masrafların önlenmesi ve milli değerlerin kayba uğratılmamasının sağlanması olduğunu, Yüksek Planlama Kurulunca faaliyet konuları belirlenen sınai tesislerin kurulması halinde ekolojik dengenin nasıl etkileneceğinin ortaya konulması amacıyla bilirkişi incelemesi yapılmasına karar verildiğini, bilirkişilerce; halen mevcut sanayi tesislerinin bölgede kirliliğe sebebiyet verdiği ve ekolojik dengeyi olumsuz yönde etkilendiğini gösterir nitelikte olduklarının vurgulandığını, sonuç olarak, dava dosyası içeriği ve bilirkişi raporunun kesin sonuçlarından Bakanlar Kurulu kararıyla öngörülen serbest bölgedeki enerji üretim faaliyetleriyle sınai tesislerin işletmeye açılması halinde ekolojik dengenin olumsuz etkileneceğinin anlaşıldığı gerekçesi ile Bakanlar Kurulu kararının iptaline karar verilmiştir. 
Çevre Bakanlığının 1sınmada petrol kok kullanımının yasaklanmasına ilişkin 13.1.1995 günlü, 0175-0098-353 sayılı genelgesinin iptalinin talep edildiği davada ${ }^{38}$ Danıştay, petro kok kullanımının çevreye zarar vermeden yakılabilmesinin ancak özel şartlar sağlandığında mümkün olduğu, en az 800 derecedeki bir sicaklıkta kullanılması gereken petrol kokunun konutlardaki sobalarda ısınmak amacıyla kullanılması halinde hava kirliliğine neden olacağı, bu sıcaklığın altında yakılması durumunda kanserojen etkili ve Polisiklik Aromatik Hidrokarbon olarak tanımlanan bir dizi organik maddenin atmosfere verileceği, bu maddelerin ise 2 Kasım 1986 tarihli Hava Kalitesinin Korunmas1 Yönetmeliğinde belirtilen kanser yapıcı maddeler listesinde bulunduğu, az miktardaki avantajlarına karşı yüksek oranda zehirli maddeler içerdiği, bu nedenle kullanımının da toksikolojik nedenlerden dolayı sorumluluğu altına girilemeyecek kadar tehlikeli olması yanında Türkiye şartlarına da uymadığ 1 sonucuna varmış ve dava konusu genelgede mevzuata aykırılık bulunmadığ gerekçesi ile iptal talebini yerinde bulmayarak davanın reddine karar vermiştir.

Her iki karar çerçevesinde Danıştay'ın enerji üretimi ve kullanımını çevre ile bağlantılı olarak değerlendirildiği, bir kararında ekolojik denge, diğer kararında ise çevrenin bir unsuru olan havanın kirlenmesi kavramlarını kullandığı gerek enerjinin üretiminin gerekse kullanımının ekolojik dengeye ya da çevrenin bir unsuru olan havaya olan zararlarının hukuka aykırı olduğuna karar verdiği, böylece çevre hakkının enerji ile olan yakın ilişkisini ortaya koyduğu anlaşılmaktadır.

İdarenin bir kamu hizmeti görürken faaliyetleri esnasında çevreye zarar vermesi kaçınılmazsa, bu faaliyetleri çevreyi korumaya tercih edip etmeyeceği konusunda ise Danıştay'ın vermiş olduğu bir karardan hareketle bir idari faaliyet ile doğal çevrenin korunması arasındaki bir çatışma söz konusu olduğunda çevre korumaya öncelik tanıdığının savunulabileceği ifade edilmiştir. Bahsi geçen karara konu olayda kanalizasyonu olmayan bir mahallede oluşan foseptik sızıntılarının halk sağlığını tehdit etmesi üzerine geçici bir yolla foseptiğin denize verilmesi üzerine deniz kenarında plaj işleten işletme sahibinin Belediyenin işlemine karşı açtığ davada Danıştay belediyenin yükümlü olduğu kanalizasyon sistemi kurma ödevini yerine getirmesi gerekirken atık suları denize vermesinin hukuka aykırı olduğuna hükmetmiştir. ${ }^{39}$

1982 Anayasasının 56. maddenin ilk iki fikrasının çevre hakkına özgülendiği ifade edilmiş ise $\mathrm{de}^{40}$ bu kabulün çok da isabetli olmadığı söylenmelidir.

Danıştay 6 D, 5023/2558, 28.05.1996

39 Ali D. Ulusoy, Çevre Kirlenmesinin Oluşmasından Sonraki Aşamada Medeni Hukuk, Ceza Hukuku ve İdare Hukuku Çözümlerine Genel Bir Bakış, (1993) 43(1), AÜHF Dergisi, 125, 125-142. Karar künyesi için dn. 34

40 Semiz, (n 20) 10 
IIIIIIIIII!

Herşeyden önce maddenin kenar başlı̆̆ 1 dahi "çevre" den bahsetmektedir. Maddenin sadece çevre hakkına özgülenmediği vurgulanmalıdır zira 56/1. madde sağliklı ve dengeli bir çevrede yaşama hakkından söz etmektedir. Dolayısıyla bireyin sağlıklı ve dengeli bir çevrede yaşamasına imkan tanıyacak unsurların 56/1. madde içeriğine dahil olduğu söylenebilir. ${ }^{41}$ Ayrıca yaşama hakkının somutlaşabilmesi için sağlık ve çevre hakkının sıkı ilişki içinde olan haklar oldukları da ifade edilmiştir. ${ }^{42} \mathrm{Bu}$ kapsamda çevreyi kirleten yani beyaz olmayan enerjinin sağlıklı ve dengeli bir çevreyi olumsuz etkileyeceği muhakkak olacağından beyaz enerjinin de sağlıklı ve dengeli bir çevrede yaşama hakkına mündemiç olduğu ortadadır. ${ }^{43}$ Kaldı ki 56 . maddenin 2. fikrası çevreyi geliştirmenin, çevre sağlı̆̆ını korumak ve çevre kirlenmesini önlemenin Devletin ve vatandaşların ödevi olduğunu düzenleme altına almıştır. $\mathrm{Bu}$ çerçevede beyaz enerji hakkının anayasal dayanağının bulunduğu ve bunun da 56/1. ve 2. fikraları olduğu söylenebilir.

\section{Yasal Bağlamda Beyaz Enerji Hakkı}

Beyaz enerji ilekastedilenin çevreyi kirletmeyen enerji olduğu belirlendikten sonra beyaz enerji hakkının yasal bağlamda ne şekilde düzenlendiğine de bakılması gerekmektedir. Bu konuda tıpkı Anayasada olduğu gibi yasal bir düzenleme mevzuatımızda yer almamaktadır. Ancak yukarıda anayasal dayanak olduğu kabul edilen 56. madde hükmü esas alınarak, yasal temeli de bu çerçevede aramak gerekmektedir.

Anayasanın 56. maddesi, sağlıklı bir çevrede yaşama hakkını herkese tanımış, çevre kirlenmesini önlemeyi Devlete ve vatandaşlara bir ödev olarak yüklemiş olup anayasal bu hak karşılığını 2872 sayılı Çevre Kanunu'nun "İlkeler" başlıklı 3/1-e maddesinde bulmaktadır. Anılan düzenlemede Çevre ve Şehircilik Bakanlığ 1 ve yerel yönetimlere; meslek odaları, birlikler, sivil toplum kuruluşları ve vatandaşların çevre hakkını kullanacakları bir katılım ortamını yaratmak yükümlülüğü yüklenerek, çevre hakkının varlığı açıkça zikredilmiştir. Ayrıca Kanun'da çevre hakkının kullanılmasına ilişkin bazı usuli hükümlerin de bulunduğu görülmektedir. ${ }^{44}$ Gerçekten Kanunun 30/1.

41 Bu noktada 2872 sayılı Çevre Kanunu 2. maddesinde yer alan ekolojik denge kavramı için yapılan "İnsan ve diğer canlıların varlık ve gelişmelerini doğal yapılarına uygun bir şekilde sürdürebilmeleri için gerekli olan şartların bütünü” tanımı da vurgulanmalıdır.

42 Memiş, (n 15) 348

43 Benzer şekilde güneşe ve rüzgâra erişim hakkının çevre hakkına dahil olduğu, güneş ve rüzgâra erişimin olmadığı bir çevrenin sağlklı bir çevre sayılamayacağı dolayısıyla kişinin çevre hakkına aykırı bir durumun ortaya çıkacağı ifade edilmiştir. Ayşe Özcan, Sürdürülebilirlik Ekseninde "Yeni Çevresel Haklar Deneyimi" Ve Eko-Politik Bir Analiz: "Güneş Ve Rüzgâr Hakları, (2016) 8(1), Alternatif Politika, 34, 43-44

44 Hakan Olgun and Volkan Işsk. Bir İnsan Hakkı Olarak Çevre Hakkı ve Türk Hukukundaki Yeri, (2017) 3(1), Uluslararası Politik Araştırmalar Dergisi, 33, 45 
maddesinde çevreyi kirleten veya bozan bir faaliyetten zarar gören veya haberdar olan herkesin ilgili mercilere başvurarak faaliyetle ilgili gerekli önlemlerin alınmasını veya faaliyetin durdurulmasını isteyebileceği belirtilerek "Başvuru Hakkı" na sahip olduğu düzenlenmişken, 30/2. maddesinde ise herkesin, 4982 sayılı Bilgi Edinme Hakkı Kanunu kapsamında çevreye ilişkin bilgilere ulaşma hakkına sahip olduğu düzenlenerek "Bilgi Edinme Hakkı" na sahip olduğu ifade edilmiştir.

Anayasanın 56. maddesinde çevre kirlenmesini önleme ödevi ise yasal karşı1ığını 2872 sayılı Çevre Kanunu'nda bulmaktadır. Anılan Kanunun 3/1-a maddesine göre başta idare, meslek odaları, birlikler ve sivil toplum kuruluşları olmak üzere herkes, çevrenin korunması ve kirliliğin önlenmesi ile görevli olup bu konuda alınacak tedbirlere ve belirlenen esaslara uymakla yükümlüdür. $\mathrm{O}$ halde çevrenin beyaz olmayan enerji kullanımı yolu ile kirletilmemesi bir ödev olarak en başta idareye ve sonra herkese ödev olarak yüklenmiştir. Bu ödevin bir gereği olarak idare-Devlet- gerekli mevzuat değişikliklerini de yapmakla yükümlü olup enerji ile çevre arasında var olması gereken uyumun sağlanması ve korunması bir ödev olarak idareye aittir. Bu doğrultuda 1 nolu Cumhurbaşkanlığ Kararnamesinde ${ }^{45}$ yer alan bir düzenleme bu ödevi somutlaştırmaktadır. Gerçekten Enerji ve Tabi Kaynaklar Bakanlığının hizmet birimleri arasında yer alan Enerji Verimliliği ve Çevre Dairesi Başkanlığının görevleri arasında "...çevre-enerji ilişkisi kapsamında mevcut ve yeni mevzuatın uyum ve etki değerlendirmelerini yapmak, çevre mevzuatına uyuma yönelik takip ve izleme komisyonu sekretaryasını yürütmek" de sayılmıştır.

Çevre Kanunu'nun 1. maddesinden Kanunun çevreyi sürdürülebilir kalkınma ilkesini de esas alarak korumayı amaçladığı anlaşılmaktadır. BM Genel Kurulunun yukarıda bahsedilen Sürdürülebilir Kalkınma Amaçları ve amaçlar için belirlenen göstergeler arasında çevreye duyarlı enerjiye ve enerji teknolojilerine erişimi Sürdürülebilir Kalkınmanın amaç ve göstergeleri arasında saymaktadır. Bu kapsamda Çevre Kanunu Sürdürülebilir Kalkınma ilkesi kapsamında çevreyi koruyacaksa bunu yapması için temiz enerjinin ve temiz enerji teknolojilerinin kullanımını gösterge olarak kullanması ve bu doğrultuda alt düzenlemeler yapması gerekmektedir. Özetle Çevre Kanunu Sürdürülebilir Kalkınma ilkesini benimsemekle bu ilkenin amaçlarını da benimsemiş dolayısıyla temiz enerjiyi bir hak olarak kabul etmiş olmaktadır.

Burada bahsedilmesi gereken bir diğer kanun 5346 sayılı Yenilenebilir Enerji Kaynaklarının Elektrik Enerjisi Üretimi Amaçlı Kullanımına İlişkin Kanun'dur. Kanun 1. maddesinde amaçları arasında sera gazı emisyonlarının azaltılmasını, atıkların değerlendirilmesini ve çevrenin korunmasını sayarak,

45 Cumhurbaşkanlığı Teşkilatı Hakkında Cumhurbaşkanlığı Kararnamesi, RG 10.07.2018/30474 
IIIIIIIIII!

çevre ve enerji arasındaki bağı göz önüne sermiştir. Yine 5627 sayılı Enerji Verimliliği Kanunu da 1. maddesinde enerji kaynaklarının ve enerjinin kullanılmasında verimliliğin artırılmasını hedefleyerek bu hedefin sebepleri arasına çevrenin korunmasını da dahil etmiştir.

Gerek çevre gerekse enerji ile ilgili anılan bu yasal düzenlemeler hep birlikte değerlendirildiğinde, çevre ile enerji üretim ya da kullanımı arasında sıkı bir bağ olduğu, özellikle çevrenin kirletilmemesini istemenin bir hak, çevreyi kirletmemenin ise bir ödev niteliği taşıması sebebi ile, çevreyi kirletmeyecek enerji üretimi ya da kullanımını talep etmenin de çevre hakkına mündemiç bir hak olduğu sonucuna varılabilir. Sonuçta hak ve ödev kavramları bir madalyonun iki yüzü gibidir. ${ }^{46}$

\section{Beyaz Enerji Hakkının İçeriği}

Beyaz enerji hakkı, sahibine sağladığı yetkiler ve muhataplarına yüklediği yükümlülükler temelinde şu unsurları içermektedir:

- Herkes için temiz enerji kullanma yükümlülüğü

- Tedarikçiler için temiz enerji sağlama yükümlülüğü

- Bireyler için temiz enerji talep yetkisi

\section{Herkes İçin Temiz Enerji Kullanma Yükümlülüğü}

Beyaz enerji kullanma yükümlülüğü, bazı düzenlemelerde hâlihazırda somutlaştırılmıştır. Çevre Kanunu'nun 3/1-f maddesine göre her türlü faaliyet sırasında doğal kaynakların ve enerjinin verimli bir şekilde kullanılması amacıyla atık oluşumunu kaynăgında azaltan ve atıkların geri kazanılmasını sağlayan çevre ile uyumlu teknolojilerin kullanılması esastır. Aynı maddenin $\mathrm{h}$ bendine göre de çevrenin korunması, çevre kirliliğinin önlenmesi ve giderilmesi için uyulması zorunlu standartlar ile vergi, harç, katılma payı, yenilenebilir enerji kaynaklarının ve temiz teknolojilerin teşviki, geri kazanım katılım payı, plastik poşet ve plastik ambalaj kullanımının azaltılması, depozito uygulaması, emisyon ücreti, kirletme bedeli ve kirliliğin önlenmesine yönelik teminat alınması ve karbon ticareti gibi piyasaya dayalı mekanizmalar ile ekonomik araçlar ve teşvikler kullanılır. Son olarak Kanunun Ek 6. maddesine göre hava kalitesinin korunması ve hava kirliliğinin önlenmesi için, ulusal enerji kaynakları öncelikli olmak üzere, Bakanlıkça belirlenen standartlara uygun temiz ve kaliteli yakıtların ve yakma sistemlerinin üretilmesi ve kullanılmas1 zorunludur. Görüleceği üzere tüm bu düzenlemelerin ortak özelliği çevrenin kirletilmesine engel olacak yani beyaz enerjinin kullanılmasını öngörmesidir.

46 Bunun yanı sıra 1982 Anayasa 56. maddede düzenlenen çevre hakkı aynı anda sahibine hem hak hem de ödev yüklemektedir. Kemal Gözler, İnsan Hakları Hukukuna Giriş, (Birinci Bask1, Ekin Yayınc1lık, 2017) 49-50 
Öte yandan Elektrik Piyasası Kanunu 1. maddesinde elektriğin çevreye uyumlu bir şekilde tüketiciye sunulması amacından bahsedildiği ve çevreye uyumun modern kamu hizmeti ilkeleri arasında yer aldığı ifade edilmiştir. ${ }^{47}$

\section{Tedarikçiler İçin Temiz Enerji Sağlama Yükümlülüğü}

Beyaz enerji tedarik etme yükümlülügünde önce tedarik kavramına değinmek gerekmektedir. 6446 sayılı kanunun ${ }^{48} 3$. maddesinde yer alan tanımda tedarik, "Elektrik enerjisinin ve/veya kapasitenin toptan veya perakende satışı" şeklinde ifade edilmiştir. Bu bağlamda bu tedarik yükümlülüğünün beyaz enerji kullanarak yerine getirilmesi noktasına değinmek gerekmektedir. 5627 sayılı Enerji Verimliliği Kanunu ${ }^{49} 1$. maddesinde kanunun amaçları arasında çevrenin korunması için enerji kaynaklarının ve enerjinin kullanımında verimliliğin artıılmasını da saymıştır. Enerjinin tedariği enerji kaynaklarının kullanımını gerektireceğinden enerji kaynaklarının kullanımında çevrenin korunması dikkate alınmas1 gereken konular arasındadır. Yine 3213 sayılı Maden Kanunu ${ }^{50}$ 3. maddesinde madencilik faaliyetlerinin tanımını yaparken maden işletmelerinin kapatılması ve çevre ile uyumlu hale getirilmesi ile ilgili tüm faaliyetlerin de maden faaliyetleri kapsamına girdiğini vurgulamıştır. Madencilik faaliyetlerinin temelinde enerji kaynaklarına ulaşma yatmakta olup bu faaliyetlerin çevre ile uyumlu hale getirilmesi ile kastedilen bu faaliyetlerin çevreyi kirletmemesi dolayısıyla beyaz enerji kullanımını sağlayacak şekilde yürütülmesidir. Özetle bu mevzuat düzenlemeleri beyaz enerji tedarik yükümlülüğünün varlığını ortaya koymaktadır.

\section{Bireyler İçin Temiz Enerji Talep Yetkisi}

Beyaz enerji talep yetkisi bireyin temiz bir enerji kaynağından elde edilmiş enerjiyi kullanmayı talep edebilmesini, bu bağlamda enerjinin kaynağını öğrenme ve buna göre seçim yapabilmesini gerektirir. İngiltere'de tüketicilerin tükettikleri enerjinin kaynağını seçme hakkını elde ettikleri ifade edilmektedir. ${ }^{51}$ Benzer şekilde Amerika Birleşik Devletlerinde de yenilenebilir nitelik taşıyan ve çevreye zarar vermeyen pek çok alternatif enerji kaynağ 1 bulunduğu ve enerjinin kaynağını seçme hakkının olduğu belirtilmektedir. ${ }^{52}$

\footnotetext{
Çağdaş Evrim Ergün, Elektrik Piyasasında Kamu Hizmeti, (Birinci Baskı, Çakmak Yayınevi, 2010) 209

48 Elektrik Piyasası Kanunu, Kanun Numarası: 6446, Kabul Tarihi:14.03.2013, RG 30.03.2013/28603

49 Enerji Verimliliği Kanunu, Kanun Numaras1, 5627, Kabul Tarihi:18.04.2007, RG 02.05.2007/26510

50 Maden Kanunu, Kanun Numaras1:3213, Kabul Tarihi: 04.06.1985, RG 15.06.1985/18785

51 Oktay Öğ̈̈nç, Nükleer Çöplük mü? Temiz Enerji mi? (1999) 404, Türkiye Mühendislik Haberleri, 13

52 Allen Green, Consumer Options For Choosing Renewable Energy, (www.judithcurry.com), https://judithcurry.com/2011/08/30/consumer-options-for-choosing-renewable-energy/ Erişim Tarihi:10.01.2021
} 
Türkiye açısından duruma bakılacak olursa ülkemizde elektrik piyasasındaki reform faaliyetlerinin en önemli sebeplerinden birisi tüketicilere kendi tedarikçilerini seçme hakkının verilmesidir. ${ }^{53} 6446$ sayılı Kanun ile serbest tüketici statüsünde bulunan tüketiciler tedarikçisini seçme hakkına sahip k1lınmıştır. O halde serbest olan ve olmayan şeklinde yapılan tüketici ayrımı, tüketicinin tedarikçisini seçme imkânı olup olmamasına göre yapılmaktadır. Tedarikçisini seçme imkânı ise şu üç yoldan birisiyle mümkün olmaktadır:

- Kurul tarafindan belirlenen elektrik enerjisi miktarından daha fazla tüketimi bulunmak

- İletim sistemine doğrudan bağlı olmak

- Organize sanayi bölgesi tüzel kişiliğini haiz olmak

4628 sayılı Enerji Piyasası Düzenleme Kurumunun Teşkilat ve Görevleri Hakkında Kanunun 5/6-b maddesinde Enerji Piyasası Düzenleme Kurulunun görevleri arasında her yılın ocak ayının sonuna kadar, serbest tüketici tanımına ilişkin limitlerdeki indirimleri belirlemek ve yeni limitleri yayımlamak da sayılmıştır. Enerji Piyasas1 Düzenleme Kurumunun 17.12.2020 tarih ve 9814 sayılı kararı ile 2021 yılı için serbest tüketici limiti $1200 \mathrm{kWh}$ olarak belirlenmiştir. Dolayısıyla yıllık elektrik tüketimi bu miktarı aşan tüketiciler tedarikçilerini seçebilecekler ve bu bağlamda temiz enerji kaynağı kullanarak elektrik üreten bir tedarikçiyi tercih edebileceklerdir. Fakat bu noktada iki sorun karşımıza çıkmaktadır. Birincisi tedarikçinin kullandığı enerji kaynağını bildirme yükümlülügü var mıdır? İkincisi ise temiz enerji kaynağı kullanan hiçbir tedarikçi yok ise tüketicinin ne yapacağıdır?

Enerjinin kaynağını bildirme yükümlülüğ̈̈ ile ilgili mevzuatımızda bildirim yükümlülüğünü içeren bir düzenleme bulunmamaktadır. ${ }^{54}$ Ancak burada konu ile ilgisi açısından Ürünlerin Enerji Ve Diğer Kaynak Tüketimlerinin Etiketleme Ve Standart Ürün Bilgileri Yoluyla Gösterilmesi Hakkında Yönetmelik'ten ${ }^{55}$ söz edilmelidir. Anılan Yönetmelik etiketleme ve standart ürün bilgileri yoluyla enerji ile ilgili ürünlerin kullanım sırasındaki enerji ve diğer temel kaynak tüketimleri konusunda nihai kullanıcıların bilgilendirilmesini ve bu

53 Ercüment Camadan, Tedarikçi Seçme Özgürlüğü ve Hukuki Ayrıştırmanın Düzenlenen Elektrik Piyasası Fiyatları Üzerindeki Etkileri, (2014) 3(1), Enerji Hukuku Dergisi, 138

54 Burada enerji kaynağını sertifikalama örneği olarak kurumların ve ürünlerin toplam enerji tüketimlerinin belli bir kısmının (en az \%25) rüzgâr enerjisinden sağlandığını gösteren, tüketicilere yönelik küresel yenilenebilir bir sertifikasyon sistemi olarak windmade örneği söylenebilir. Windmade hakkında daha geniş bilgi için bkz. (www.wwf.org.tr), https://www. wwf.org.tr/ne_yapiyoruz/iklim_degisikligi_ve_enerji/iklim_degisikligiyle_mucadele_ve_ is_dunyasi2/windmade/

55 Ürünlerin Enerji ve Diğer Kaynak Tüketimlerinin Etiketleme ve Standart Ürün Bilgileri Yoluyla Gösterilmesi Hakkında Yönetmelik, Karar No:2011/2257, RG 02.12.2011/28130 
şekilde daha verimli ürünleri tercih etmelerini sağlamak amacını taşımakta olup enerji ile ilgili ürünlerin kullanımı sırasındaki enerji tüketimleri konusunda tüketicilerin bilgilendirilmesinden bahsetmekte, bu bilgi sayesinde de tüketicinin daha verimli ürünlere yönelmesi sağlanmaya çalışılmaktadır. Görüldüğü üzere Yönetmelik enerji verimliliğini sağlamaya yönelmiştir ve enerji verimliliği ile kastedilenlerden birisi de çevrenin korunması için enerji kaynaklarının ve enerjinin kullanımında verimliliğin artırılmasıdır. Bu sebeple Yönetmeliğin enerji verimliliğini sağlayacak dolayısıyla çevre korumasına yönelik enerjinin üretilmesinde kullanılan kaynak hakkında bilgilendirmeyi de kapsadığı söylenebilir. Bu doğrultuda Yönetmelikte gerekli değişiklerin yapılarak bir ürünün üretilmesinde kullanılan enerji kaynağını da gösterecek şekilde etiketlemenin genişletilmesi ve bu sayede çevreye duyarlı enerji kullanımının tüketicinin tercihleri doğrultusunda seçebileceği seçenekler arasına koyulması sağlanabilir.

Tüketicinin temiz enerji kaynağı kullanan hiçbir tedarikçi bulunmaması halinde seçim hakkının bir öneminin bulunmadığı söylenebilir. Burada ise kişinin kendi enerjisini kendisinin üretebilmesi akla gelmektedir. Belirtmek gerekir ki bireyin elektrik kullanımına ilişkin tedarikçi ile bir sözleşme yapması zorunlu olmayıp abonelik sözleşmelerinde de bir sözleşmenin yapılabilmesi için ilk önce tarafların kendi aralarında, objektif ve sübjektif bakımından esaslı noktalar üzerinde anlaşmış olmaları gerekmektedir. ${ }^{56}$ Dolayısıyla temiz enerji kaynağ1 kullanan hiçbir tedarikçi yok ise tüketicinin abonelik sözleşmesi yapma zorunluluğu da bulunmamaktadır. Bu durumda ise tüketici, 6446 sayılı Kanunun 14. maddesinde tanınan imkândan faydalanabilecek ve lisans alma zorunluluğu olmaksızın kurulu gücü azami bir megavat olmak koşulu ile yenilenebilir enerji kaynaklarına dayalı üretim tesisi kurabilecek ve kendi enerjisini üretebilecek ve ihtiyacı olan enerjiyi bu şekilde temin edebilecektir.

\section{Dünya'da Beyaz Enerji Açısından Durum}

Dünyada çevreyi kirletmeyen, beyaz enerji kullanımını yasal olarak düzenleme altına alan ülkeler olup olmadığına bakmak gerekmektedir. Burada ilgili yasanın adından hareket edilecek ise de yasanın içeriğinde beyaz enerji ile kastedilenin temiz enerji olup olmadığı incelenecek, yenilenebilirlikle yapmaya çalıştığımız ayrıma yasada yer verilip verilmediği anlaşılmaya çalış1lacaktır. Değilse, "Temiz Enerji" ya da "Yeşil Enerji” gibi isimleri taşıyan yasaların içeriğine bakmadan temiz enerjiyi düzenlediklerini peşinen kabul etmek hatalı sonuçlara varılmasına yol açabilecektir.

Avrupa temelinde 17 Aralık 1994'de imzalanarak Nisan 1998'de yürürlüğe giren Enerji Şartı Anlaşması Avrupa'nın enerji politikasında kilometre

56 Fikret Eren, Borçlar Hukuku Genel Hükümler, (Yirminci Bask1, Yetkin Yayınları, 2016) 246 
IIIIIIIIII!

taşlarından birisidir. Ülkemiz tarafindan da 4519 sayılı Kanunla onaylanması uygun bulunan anlaşmanın amaçlarından birisi de çevreye olan olumsuz etkilerin en aza indirilmesidir. ${ }^{57}$

\section{Amerika Birleşik Devletleri}

Amerika Birleşik Devletleri'nde halen yürürlükte olan “American Clean Energy and Security Act of 2009" ${ }^{58}$ her ne kadar Temiz Enerji başlığını taşısa da temiz enerjinin tanımına yer vermemiştir. Kanun, temiz enerji, enerji verimliliği, küresel ısınmanın azaltılması, temiz enerji ekonomisine geçiş gibi konularda hükümler içermektedir. Kanunun 1. Başlığı "Temiz Enerji” başlığı taşımakta, bu başlıkta tanımlar kısmında "Yenilenebilir Elektrik", yenilenebilir enerji kaynaklarından ya da diğer nitelikli enerji kaynaklarından üretilen elektrik olarak tanımlanmaktadır. Görüldügü üzere tanım yenilenebilir enerji kaynaklarının yanı sıra diğer nitelikli enerji kaynaklarından bahsetmektedir. Kanunda "Yenilenebilir Enerji Kaynakları"; rüzgâr, güneş ve jeotermal enerji, yenilenebilir biokütle, biyogaz ve münhasıran yenilenebilir biokütleden elde edilen biyoyakıtlar, nitelikli hidroelektrik ile deniz kaynaklı ve hidrokinetik yenilenebilir enerji olarak sayma yolu ile belirtilmiştir. Diğer nitelikli enerji kaynakları ise; çöp gazı, atık su arıtma gazı, maden ağzında ya da yakınında elektrik üretmek için kullanılan kömür madeni metan gazı ile enerji üretimine uygun nitelikli atık olarak sayılmıştır.

Kanunun B alt başlığı 1. kısmında "Yeşil İşler" başlığında, Eğitim Bakanının, temiz enerji, yenilenebilir enerji, enerji verimliliği, iklim değişikliğini azaltma ve iklim değişikliğine uyum alanlarında ortaya çıkan kariyer ve işlere odaklanan çalışma programları geliştirmek için uygun ortaklıklara hibe verme yetkisinin bulunduğu ifade edilerek temiz enerji ve yenilenebilir enerji kavramlarının ayrı ayrı zikredildiği görülmektedir. Kanun ayrıca yine bu Kanunla kurulan Temiz Enerji Dağıtım İdaresinin temiz enerji projelerini finansal açıdan destekleyebilmesi için Temiz Enerji Yatırım Fonunu kurmuştur. Kanun Temiz Enerji Dağıtım İdaresini temiz enerji teknolojileri kullanımı için doğrudan kredi verme, teminat mektubu verme ve kredi garantisi verme konularında yetkili kılmıştır.

Kanunun bu düzenlemeleri birlikte değerlendirildiğinde Kanunun adında yer alan bir kavramın tanımının yapılmayıp, yenilenebilir elektrik ve yenilenebilir enerji kaynaklarının tanımını yapması bir handikap olarak akla gelebilir. Ancak yenilenebilir elektrik kavramının tanımlanmasında sadece yenilenebilir enerji kaynaklarına değil, diğer nitelikli enerji kaynaklarına da atıf yapması, özellikle bu son kaynaklar arasında yenilenebilirlik özelliği olmayan "maden

57 Çağdaş Evrim Ergün, Avrupa Birliği Enerji Hukuku, (Birinci Baskı, Çakmak Yayınevi, 2007) 78-81

58 American Clean Energy and Security Act of 2009 (www.congress.gov) https://www. congress.gov/bill/111th-congress/house-bill/2454 Erişim Tarihi: 28.06.2021 
ağzında ya da yakınında elektrik üretmek için kullanılan kömür madeni metan gazına" yer vermesi, Kanunun yenilenebilirlik ile temiz olma kavramlarını farklı gördügü şeklinde yorumlanabilir. Keza "Yeşil İşler" kısmında temiz enerji ve yenilenebilir enerji kavramlarının ayrı ayrı zikredilmesi ve son olarak temiz enerji projelerinden bahsederek bir "Temiz Enerji Dağıtım İdaresi”nin varlığı, "Beyaz Enerji”nin bu Kanunda yenilenebilir enerjiden ayrı, bağımsız bir kavram olarak tanımlandığına yönelik ciddi bir diğer emaredir.

\section{Avusturya}

Avusturya' da "Clean Energy Act 2011" ${ }^{9}$ ismi ile yürürlükte olan bir kanun varken bunun yanı sira "Renewable Energy (Electricity) Act 2000" adiyla bir kanun daha bulunmaktadır. "Clean Energy Act 2011" in amac1, temiz enerji kullanımını teşvik ederek iklim değişikliğiyle başa çıkmak için bir mekanizma kurmak olarak belirtilmiştir. Yine Kanunda Temiz Enerji Düzenleme Birimi tarafından karbon birimi ihraç edilebileceği, kömür kullanarak elektrik üreten birimler için ise ücretsiz karbon birimlerinin ihraç edileceği düzenleme altına alınmış, kömürle elektrik üreten birimlerin belirlenmiş uygunluk kriterlerini sağlamaları koşulu ile ücretsiz karbon birimi ihraç edebilecekleri hükme bağlanmıştır. Yine Kanun kömürle üretim tesislerine yardım için uygunluk sertifikasından bahsederek, bu sertifikanın alım koşulları detaylı bir şekilde düzenlenmiştir.

"Renewable Energy (Electricity) Act 2000"60 in amaçları ise yenilenebilir kaynaklardan ilave elektrik üretimini teşvik etmek, elektrik sektöründe sera gazı salınımını azaltmak ve yenilenebilir enerji kaynaklarının ekolojik olarak sürdürülebilir olmasını sağlamak olarak ifade edilmiştir. Kanunda yenilenebilir enerji kaynakları, "Uygun Yenilenebilir Enerji Kaynakları" başlığı altında sayma yolu ile uzun bir liste verilmiştir. Ancak yapılan sayım sınırlı değildir. $\mathrm{Bu}$ listeye göre şunlar "Uygun Yenilenebilir Enerji Kaynakları" dır: Hidro, Dalga, Gel-git, Okyanus, Rüzgâr, Güneş, Jeotermal, Sıcak Kuru Kayalar, Enerji Bitkileri, Odun Atığı, Zirai Atık, Zirai Ürün, İşleme Atığı, Gıda Atı̆̆ı, Gıda İşleme Atığı, Küspe, Siyah Likör, Biyokütle, Çöp Gazı, Kanalizasyon Gazı, Biokütle Esaslı Kanalizasyon Bileşenleri ve düzenlemelerde belirlenen diğer enerji kaynakları.

Kanun, fosil yakıtlarla fosil yakıtlardan elde edilen madde ve atıkların ise "Uygun Yenilenebilir Enerji Kaynağı" olamayacağını düzenlemiştir.

Avusturya düzenlemeleri bir kere temiz enerji ve yenilenebilir enerjiyi farkl1 kanunlarda düzenleyerek bu iki konuyu ayırdığını açıkça ortaya koymuştur.

59 Clean Energy Act 2011, (www.legislation.gov.au) https://www.legislation.gov.au/Details/ C2011A00131 Erişim Tarihi: 28.06.2021

60 Renewable Energy (Electricity) Act 2000, (www.legislation.gov.au) https://www.legislation. gov.au/Details/C2019C00061 Erişim Tarihi: 28.06.2021 
IIIIIIIIII!

Dahas1 "Clean Energy Act 2011" ile iklim değişikliği ile mücadele amacı doğrultusunda, fosil yakıt kullanıcısı olan kömürlü elektrik üreticileri dahil düzenleme altına alınmıştır. Dolayısıyla fosil yakıtla çalışan bu birimlerin dahi temiz enerji ile ilgili yükümlülükleri söz konusudur ve tamamen temiz enerji ile bağlarının koptuğu söylenemez. Kaldı ki kanunda yenilenebilir enerjiye dair hiçbir düzenleme de bulunmamaktadır. Avusturya'nın bu iki kavramı farklı kanunlarda düzenlemesi olumlu olup temiz enerjinin bir tanımını yapmaması eksiklik olarak göze çarpmakta ise de kanunun iklim değişikliği ile mücadele için bir mekanizma kurmayı amaçladığı da unutulmamalıdır.

Avusturya'da garantili tarife uygulamas1, yenilenebilir enerji projelerinin gelişimini cesaretlendirmektedir. Ülkede en son yürürlüğe konulan Yeşil Enerji Kanunu çerçevesinde yasal bir yükümlülük olarak "Yeşil Elektrik Merkezi" yenilenebilir enerji kaynakları kullanarak enerji üreten kabul edilmiş üreticileri garantili tarife ile elektrik almak için imzalanan sözleşmeler çerçevesinde tercih etmektedir. Kanun yenilenebilir enerjiye yönelik önemli fonlar sağlamaktadır. ${ }^{61}$

\section{Almanya}

Avrupa'da yenilenebilir enerji alanında öncü ülke konumunda olan ve pek çok ülke için yenilenebilir enerji alanında rol model konumunda olan Almanya halihazırda dokuz adet nükleer santrali faal durumda olsa da sekiz adet nükleer santralini 2011 y1lında önce Japonya'da akabinde ise Fransa'da yaşanan nükleer patlamalardan sonra kapatarak yoğun bir biçimde yenilenebilir enerjiye yönelmiştir. ${ }^{62}$

Alman Yenilenebilir Enerji Kanununda (EEG) yapılan iki büyük reformdan sonra son değişiklikler 1 Ocak 2021 tarihinde yürürlüğg girmiştir. ${ }^{63}$ Almanya'nın yenilenebilir enerji alanında ilk düzenlemesi 2000 yılında Yenilenebilir Enerji Kanununun yürürlüğe konulması olup geniş kapsamlı değişikliklerden sonra Yenilenebilir Enerji Kanunu 2009 yürürlüğe girmiş ve son olarak da EEG2012 yürürlüğe konulmuştur. ${ }^{64}$

Almanya'nın yüzyılın ortasına kadar sera gazı salınımında nötr olma hedefi, Yenilenebilir Enerji Kanunu 2021'in resmen ana ilkesi olarak kabul edilmiştir. Hazırlanan son taslak, Kanunun amacının 2050 yılından önce

${ }_{61}$ Stefan Lampert, The Renewable Energy Review, Chapter 2 Austria, (2018, Law Business Research Ltd.) 11-17. Lampert, s.11-12

62 Mustafa Erdem Can, Alman Yenilenebilir Enerji Düzenlemeleri ve Teşvik Sistemi, (2014) 3(1), Enerji Hukuku Dergisi, 5-6

63 What's New In Germany's Renewable Energy Act 2021(www.cleanenergywire.org) https:// www.cleanenergywire.org/factsheets/whats-new-germanys-renewable-energy-act-2021 Erişim Tarihi: 28.06.2021

${ }^{64}$ Can, (n 51) 8 
Federal Almanya topraklarında üretilen ya da tüketilen elektriğin, nötr sera gazı prensibi ile üretilmesini sağlamak olduğunu ifade etmektedir.

Avrupa Birliği üye devletlerinin 2030 yllı iklim hedeflerini yükseltme kararını alması Almanya açısından ulusal emisyon azaltma hedefini ayarlaması anlamı taşımaktadır. Bu konuda Almanya Çevre Bakanı, daha katı hedeflerin, yenilenebilir enerji kaynaklarında daha hızlı bir genişleme anlamına geleceğini ifade etmiştir. ${ }^{65}$

2021 Yenilenebilir Enerji Kanununun ana ilkesinin Almanya'yı yüzyılın ortasına kadar sera gazı nötr ülke haline getirmek olduğu dikkate alındığında, kanunun beyaz enerji hedefini de içerdiği söylenebilir.

\section{4. İngiltere}

İngiltere'de 1970'lere gelindiğinde alternatif teknolojilerin gelişmesi ile yenilenebilir enerjinin teşvik edilmeye başlandığı söylenebilir. 1973 yılında yaşanan petrol krizi sonrası çevreci lobiler, alternatif enerji taleplerini yüksek sesle dile getirmeye başlamışlar. Peşi sıra 1974 yılında Enerji Teknolojileri Destekleme Birimi (ETSU) kurulmuştur. 1989 yılında çıkarılan ve İngiltere'de elektrik piyasasını özelleştiren Electiricity Act'in içine 1990 yılında fosil olmayan yakıt kullanma yükümlülüğü (NFFO) konulmuştur. ${ }^{66}$

1993 yılında duyurusu yapılan Teknoloji Tedbirleri programı kapsamında, farklı sektörlerle ilgili yapılan analizleri ortaya koyan toplam 15 rapor 1995 yılında yayınlanmıştır. Enerji sektör raporu, enerji teknolojilerinin gelişmesini şekillendirecek tek ve en önemli konunun, çevrenin korunmas1 olduğunu belirterek dokuz adet spesifik gelişim alanı tespit etmiştir. Bu alanların çoğu, daha iyi petrol çıkarma ve gaz yakma teknikleri gibi geleneksel fosil yakıt teknolojileri ile ilgili olmuştur. ${ }^{67}$

2002 yılında ise fosil olmayan yakıt kullanma yükümlülügünün (NFFO) yerini yenilenebilir enerji yükümlülüğü $(\mathrm{RO})$ almıştır. Yenilenebilir enerji yükümlülüğü (RO), 2000 yılında çıkarılan Kamu Hizmetleri Kanununda yer almış ve Kanun ${ }^{68}$ Bakana, elektrik tedarikçileri için, ülkedeki yıllık elektrik satışlarının belirli bir oranını, yenilenebilir enerji kaynaklarından üretilen elektrikten sağlama zorunluluğu getirme yetkisi vermiştir.

NFFO gibi RO'da piyasa temelli bir sistem öngörmekte ve enerji tedarik şirketlerinin, enerji üreticilerinden aldıkları her bir uygun yenilenebilir kaynaklı elektrik Megawatt başına yenilenebilir yükümlülük sertifikası ile

\footnotetext{
65 What's New In Germany's Renewable Energy Act 2021, Erişim Tarihi: 28.06.2021

66 David Elliot, Renewable Energy in the UK, Past, Present and Future (Energy, Climate and the Environment), (First Edition, Palgrave Macmillan, 2019) xv

67 Elliot, (n 55) 96

68 United Kingdom, (https://www.legislation.gov.uk/) Erişim Tarihi: 28.06.2021
} 
IIIIIIIIII!

ödüllendirilmelerini öngörmektedir. ${ }^{69}$ RO'ların 2037 yılına kadar uygulanması öngörülmüş̧ür. ${ }^{70}$

Günümüzde İngiltere, piyasa rekabetini, enerji hedeflerine ulaşmada en elverişli yol olarak kabul etmekte ve piyasaların güvenli, düşük maliyetli ve temiz bir enerji sistemi oluşturmak için en esnek çözümleri getirebileceği kabul edilmektedir. ${ }^{71}$

İngiltere'nin enerji politikasında yaşanan değişim sonucunda 2017 yılında ülkede kömür ve petrolden üretilenden daha fazla elektrik yenilenebilir kaynaklardan üretilmiştir. ${ }^{72}$

\section{Fransa}

Fransa'nın geçmişte yenilenebilir enerjinin gelişimine önem vermediği söylenebilir. Durumun böyle olmasında ağırlıklı olarak ucuz nükleer enerji temini ve kömür üretiminin yavaşlaması; bu iki durumun da düşük karbon ve sülfür salınımına yol açmasının etkili olduğu söylenebilir. Bununla birlikte AB'nin çevre ve yenilenebilir enerji alanlarındaki Direktifleri Fransa'ya bir ivme kazandırmıştır.

Yenilenebilir enerji ile ilgili biokütle Fransa'da önem taşıan bir enerji kaynağ1 olup biokütleden enerji üretimine dair araştırmalar 1982'den beri yapılmaktadır. Fransa AB'de uzak ara en büyük biokütle enerjisi tüketicisi konumundadır. Fransa'nın biokütle kullanımının \%18'ini evsel katı atıklardan elde edilen enerji oluşturmaktadır. Evsel katı atıklar, bazıları çok zehirli bazıları ise tehlikesiz olan çeşitli maddelerin karışımını içermektedir. Evsel katı atık işleyen fabrikaların etkili çevre yönetimleri, evsel katı atıktan üretilen yakıttan zehirli maddeleri çıkarmayı ve atıktan enerji üreten fabrikaların hava kirliliği salınımlarını kontrol altına almayı amaçlamıştır. 1994 yılında kısa adı AGRICE olan Kimya ve Enerji için Zirai Araştırma Grubu kurulmuş olup Grubun amaçları arasında çevrenin korunması da yer almaktadır. Grup, kısa adı ADEME olan, endüstri ve sanayi alanlarında Çevre, Sanayi ve Araştırma Bakanlıklarının ortak sorumluluğunda faaliyette bulunan resmi bir organ konumundaki Fransa Çevre ve Enerji Yönetim Ajansı tarafından koordine edilmekte ve yönetilmektedir.

69 Elliot, (n 55) 132

70 National Renewable Energy Action Plan for the United Kingdom Article 4 of the Renewable Energy Directive 2009/28/EC (www.assets.publishing.service.gov.uk) https:// assets.publishing.service.gov.uk/government/uploads/system/uploads/attachment_data/ file/47871/25-nat-ren-energy-action-plan.pdf Erişim Tarihi: 28.06.2021, s.15

71 Elliot, (n 55) 305

72 John Dewar and Kilian de Cintre, The Renewable Energy Review, Chapter 15 United Kingdom, (2018, Law Business Research Ltd.) 154 
Fransa'da 1994 yılından itibaren Fransız Elektrik İdaresine, satın alacağ elektriği, biokütle kullanan üreticilerden alma yükümlülüğü getirilmiştir. ${ }^{73}$

1970'lerin başında yaşanan Petrol krizi, Fransa'yı dışa bağımlılığı azaltmak adına nükleer enerji endüstrisini geliştirmeye yöneltmiştir. Bununla birlikte Fransa'nın nükleer programı, 1971 yılında Çevre Bakanlığının kurulması ile başlayan çevre koruma çabalarının önemli bir ögesi haline gelmiştir. Fransa, nükleer enerji seçeneklerini geliştirip zenginleştirerek, Çevre Bakanlığının; çevreyi gözlemek, doğayı korumak, kirliliği ve diğer zararları önlemek, azaltmak ya da tamamen yok etmek ve yaşam kalitesini artırmak misyonlarına bağlı kalmayı da başarmıştır. Her ne kadar nükleer atıkların uzun dönemde imhasına ilişkin önemli sorular akıllara gelse de Fransa nükleer enerji kullanımı ile karbon salınımı ve sera gazlarından kaynaklanan kirliliği azaltııştır.

Fransa günümüzde hava kirliliği sorunu yaşamaya devam etmektedir. Fransa Çevre ve Enerji Yönetim Ajansı (ADEME), hava kirliliği ile mücadele için, Hava Kirliliği Yasası çerçevesinde ülkeyi bir izleme sistemi ile donatmaktadır.

Karbon salınımı noktasında ise Fransa 2000 yılında karbon salınımını kontrol altına almaya yönelik 2000-2010 yıllarına ilişkin bir plan hazırlamıştır. Plan, salınan metrik ton karbon başına 23-30 USD arasında değişen ve 2010 yılına kadar 75 USD'ye kadar çıkması öngörülen bir vergi içermektedir. Anılan bu vergi, 1999 tarihli bir ekoloji vergisi olan ve aşama aşama enerji tüketen faaliyetlere ve enerji üreticilerini de kapsayacak olan Kirletici Faaliyetler Genel Vergisine uygulanmıştır. 2002 tarihli bir resmi raporda Fransız sanayisinin 1990-2001 döneminde salınımları \%25, enerji üretim şirketlerinin ise \%22 oranında azalttığı belirtilmiştir.

Fransa'nın kömür gibi fosil yakıtlardan nükleer enerjiye doğru kayması, karbon salınımı seviyesinin azalmasında açıkça kendini göstermektedir. Enerji ile çevre ilişkisinde özellikle yaşanan iki tanker sızıntısı vakasından sonra Fransa çevre koruma konusunda daha koruyucu bir yaklaşım benimsemiştir. 2003 yılında Hükümet, Fransa Anayasasını, çevre korumayı insan hakları ile eşit güce getirecek şekilde değiştirecek bir planı kabul etmiştir.

Fransa, Avrupa Birliğinin "Yeşil Belge" sine uyum çerçevesinde de öncü konumundadır. $\mathrm{Bu}$ doğrultuda Fransız şirketleri, su ve doğal kaynakları kullandıklarında ortaya çıkan sera gazı salınımlarını ve enerji tüketimlerini, çevresel riskleri azaltmak için aldıkları tedbirleri ve çevre yönetimi konusunda çalışanlara verdikleri eğitimleri raporlamak zorundadır. ${ }^{74}$

73 EEBR France: Energy \& Environment Business Report, Renewables, (www.eds.a.ebscohost. com) http://eds.a.ebscohost.com/eds/pdfviewer/pdfviewer?vid=0\&sid=0a454d76-c7464fd4-b226-447d7c8f68cd\%40sdc-v-sessmgr02 Erişim Tarihi: 28.06.2021

74 EEBR France, Erişim Tarihi: 28.06.2021 
IIIIIIIIII!

\section{6. Çin}

Çin kendine has özellikleri ile kalabalık nüfusu, artan endüstrileşme ve kentleşme süreci olan bir ülkedir. Bu özellikleri Çin'i en çok enerji tüketen ülkelerden birisi haline getirmiş olup Çin'in birincil enerji tüketimi ve elektrik tüketiminin \%70'nin kömürden elde edildiği görülmektedir. Buna bağlı olarak Çin dünyada Amerika Birleşik Devletlerinden sonra en fazla karbon kirliliğine yol açan ülke durumundadır. ${ }^{75}$ Çin, dünya kömür tüketiminin yarısından fazlasını dünya topraklarının yaklaşık \%2,2'sinde gerçekleştirmekte ve dolayısıyla hava, su ve toprak kirliliği yaşayan bir ülke olarak karşımıza çıkmaktadır. ${ }^{76}$

Çin'de bu ciddi tehlikelere yol açan hava kirliliğinin azaltılması, arz güvenliğinin sağlanabilmesi, yenilenebilir enerji kaynaklarının geliştirilmesi için çeşitli politikalar, hukuki düzenlemeler ve mali teşvikler uygulanmaktadır. Bunun yanı sıra Çin enerji politikalarını karbon salınımını azaltmak için de geliştirmeye çalışmaktadır. Çin'in bunu gerçekleştirebilmek için üç seneği bulunmaktadır. $\mathrm{Bu}$ seçenekler; düşük ekonomik büyüme, enerji yoğunluğun azaltılması ve yenilenebilir enerji kaynaklarının kullanılmasıdır. Çin'de ekonomik büyümenin artması, enerji tüketiminde de artışa yol açmış olup yukarıda bahsedilen seçeneklerden ekonomik büyüme oranlarının azalması etkin ve uygulanabilir bir çözüm yolu olarak nitelendirilmemektedir." ${ }^{77}$

Çin 2015 yılında ABD ile birlikte yaptıkları ortak iklim bildirisinde 2030 yılına kadar enerji tüketiminde fosil olmayan, yenilenebilir ve nükleer enerjinin payını yaklaşı \%20'ye artırmayı ve 2005 yılına nazaran karbon salınımını \%65 civarında azaltmayı hedeflediğini bildirmiştir. Bu amaçla Çin, petrol ve kömür kaynaklı hava kirliliği ve diğer çevresel sorunları çözmeye yönelik temiz enerji kullanımını teşvik etmektedir.78

Yenilenebilir enerji kaynaklarını etkileyen faktörler arasında ekonomik rekabet de karşımıza çıkmaktadır. Yenilenebilir enerji kaynaklarının kullanımına yönelik olarak özellikle teknolojik ürünlerde gelişmeler yaşandığı

75 Çin 2013 y1lında, Avrupa Birliğinin toplamından daha fazla 10 trilyon ton CO2 salınımı yapmıştır. Alvin Lin, Luan Dong and Yang Fuqiang, How China Can Help Lead A Global Transition to Clean Energy, Policy Brief, (2015) 6, Fixing Climate Governance Series, 2

76 Çin'in kömür potansiyeli kapsamında, kömürün güç üretimine yönelik olmayan kullanımlarının çevre ve eneri verimliliğinde sağlayabileceği artışlara yönelik, temiz kömür teknolojileri ile ilgili detaylı bilgi için bkz. Technology Assessment of Clean Coal Technologies for China: Environmental and Energy Efficiency Improvements for NonPower Uses of Coal, Volume II, Esmap And Easeg Technical Paper, Esmap Publications, May 2001

77 Feng Wang, Haitao Yin and Shoude Li, China's Renewable Energy Policy: Commitments and Challenges, (2010) 38(4), Energy Policy, 1872

78 Lin, Dong and Fuqiang, (n 64) 2 
görülmektedir. Bu nedenle uluslararası ticaret içerisinde bu teknoloji önemli bir yer edinmiştir. Çin'de rüzgâr türbinleri, güneş panelleri ve güneş pilleri gibi ürünlerin üretimi resmi olarak desteklenmekle ülke bu ürünlerin üretildiği, yeşil teknolojilerin üssü ve önemli bir ihracatçı haline gelmiştir.

Çin'i yenilenebilir enerji kaynaklarının kullanımına teşvik eden diğer olay, hava kirliliği ile insanların yaşam kalitelerinin olumsuz etkilenmesi olmuştur. Fosil yakıtların enerji üretiminde kullanılması ile ortaya hava, su ve toprak kirliliği ortaya çıkmakta, gıda ve su güvenliği ile insan sağlığının bu kirlilikten olumsuz şekilde etkilenmektedir. Bireylerin yaşam kalitelerinde düşmeye sebep olan bu olaylardan ötürü Çin yenilenebilir enerji kaynaklarının etkin bir şekilde kullanılması için seferber olmuştur. ${ }^{79}$ Onbirinci 5 yıllık plan (20062010) ile birlikte Çin artan enerji tüketimi kapsamında yenilenebilir enerji hukuku ile garantili tarife uygulamasını içeren bir programa geçiş yaparak kurulu rüzgâr gücünde birinci, kurulu güneş enerjisi gücünde ise Almanya'nın ardından ikinci duruma gelmiştir. ${ }^{80}$

Yukarıda da bahsedildiği üzere Çin'deki hava kirliliği sorunu ülkeyi kömür tüketiminin azaltıldığı bir enerji politikasına yöneltmiştir. Bu kapsamda ülke 2014-2020 yıllarını kapsayan Enerji Gelişim Strateji Eylem Planına 2020 yılı için 4,2 trilyon ton kömür tüketim sınırı ile birincil enerji üretiminde kömürün payını \%62'ye düşürme hedefi koymuştur. Plan, doğalgaz payını ikiye katlamanın yanı sıra daha uzak hedefler olarak düşük karbon salınımı sağlayacak hidroelektrik, rüzgâr, güneş ve nükleer enerji kaynakları kullanımını artırmayı öngörmektedir. ${ }^{81}$

\section{SONUÇ}

Çevreyi etkileyen en başta gelen faaliyetler enerji faaliyetleridir. $\mathrm{Bu}$ kapsamda enerjinin gerek üretimi gerekse tüketiminde çevresel zararları minimum seviyede olan ve temiz enerji anlamına gelen beyaz enerjinin tercih edilmesi çevrenin olumsuz etkilenmesini önlemeyi sağlayacaktır. Temiz enerji denilince akla yenilenebilir enerji kaynakları gelse de bu iki kavram aynı anlama gelmemektedir. Beyaz enerji tükenmeme özelliğine değil, temiz olma özelliğine vurgu yapmaktadır.

Beyaz enerjinin bir hak olarak uluslararası metinlerden yorum yolu ile çıkarılması mümkündür. Ancak 1982 Anayasasının 56. maddesi, sağlıklı bir çevre hakkını düzenlese de sağlıklı bir çevrenin varlığı, bu çevreyi olumsuz etkileyen durumların yokluğunu ya da sağlıklı bir çevre oluşumunu sağlayacak durumların varlığını talep etme hakkını da içermektedir. Bu açıdan

\footnotetext{
79 Kevin Lo, A Critical Review of China's Rapidly Developing Renewable Energy and Energy Efficiency Policies, (2014) 29, Renewable and Sustainable Energy Reviews, 510

80 Lin, Dong and Fuqiang, (n 64) 2

81 İbid 3
} 
IIIIIIIIII!

Anayasanın 56. maddesi, sağlıklı bir çevrenin oluşumuna katkı sağlayacak temiz enerji kullanımı talebinin Anayasal dayanağını oluşturabilmektedir. Yasal temel olarak ise başta Çevre Kanunu olmak üzere, Yenilenebilir Enerji Kaynaklarının Elektrik Enerjisi Üretimi Amaçlı Kullanımına İliş̧kin Kanun ile Enerji Verimliliği Kanunu karşımıza çıkmaktadır. Ayrıca Anayasal çerçevenin içeriği, başta Anayasa Mahkemesi olmak üzere Yüksek Mahkeme kararları ve AİHM içtihatları ile doldurulmaktadır.

Beyaz enerji hakkı, diğer tüm haklar gibi birtakım yetkiler ve yükümlülükler getirmektedir. Bu bağlamda bu hak, herkes için temiz enerji kullanma, enerji tedarikçileri için temiz enerji sağlama ve bireyler için de temiz enerji talep etme yetkisi vermektedir. Bireyler açısından özellikle temiz enerji kaynağı kullanan tedarikçilerin tercih edilmesinde serbest tüketici statüsü büyük önem taşımaktadır. Ancak bu seçimin yapılabilmesi hem tedarikçinin üretim kaynağını açıklamasına hem de temiz enerji kaynağı kullanan tedarikçinin varlığına bağlıdır.

\section{KAYNAKÇA}

Alvin L, Dong L and Fuqiang Y, How China Can Help Lead A Global Transition to Clean Energy, Policy Brief, (2015) 6, Fixing Climate Governance Series, 1-8 Aydın Aksakal P, İnsan Hakları Açısından Enerjiye Erişim Kavramı, (Birinci Bask1, Oniki Levha Yayınc1lık, 2020)

Camadan E, Tedarikçi Seçme Özgürlüğü ve Hukuki Ayrıştırmanın Düzenlenen Elektrik Piyasası Fiyatları Üzerindeki Etkileri, (2014) 3(1), Enerji Hukuku Dergisi, 135-150

Can Mustafa E, Alman Yenilenebilir Enerji Düzenlemeleri ve Teşvik Sistemi, (2014) 3(1), Enerji Hukuku Dergisi, 3-21

Çakmak M, İdare Hukuku Açısından Yenilenebilir Enerji, (Birinci Baskı, Seçkin Yayıncılık, 2018)

Turgut N, Çevre Hukuku, (Birinci Baskı, Savaş Yayınevi, 1998)

Dewar J and de Cintre K, The Renewable Energy Review, Chapter 15 United Kingdom, (2018, Law Business Research Ltd.)

Duymaz E, Avrupa İnsan Hakları Mahkemesi'nin Çevrenin Korunmasına Katkis1, (2012) 47, İstanbul Üniversitesi Siyasal Bilgiler Fakültesi Dergisi, 121-160

EEBR France: Energy \& Environment Business Report, Renewables, (www.eds.a.ebscohost.com)

http://eds.a.ebscohost.com/eds/pdfviewer/pdfviewer?vid=0\&sid=0a454d76c746-4fd4-b226-447d7c8f68cd\%40sdc-v-sessmgr02 Erişim Tarihi: 28.06.2021 
Elliot D, Renewable Energy in the UK, Past, Present and Future (Energy, Climate and the Environment), (First Edition, Palgrave Macmillan, 2019)

Eltimur Yüzer D, AİHM ve Anayasa Mahkemesi İçtihatları Işığında Çevrenin Korunmasında Devletin Pozitif Yükümlülükleri, (2018) 13(145), Terazi Hukuk Dergisi, 93-114

Energy Access Outlook 2017 From Poverty to Prosperity, (www.iea. org) https://iea.blob.core.windows.net/assets/9a67c2fc-b605-4994-8eb529a0ac219499/WEO2017SpecialReport_EnergyAccessOutlook.pdf Erişim Tarihi: 28.06.2021

Eren F, Borçlar Hukuku Genel Hükümler, (Yirminci Bask1, Yetkin Yayınları, 2016)

Ergün Çağdaş E, Avrupa Birliği Enerji Hukuku, (Birinci Baskı, Çakmak Yayınevi, 2007)

Ergün Çağdaş E, Elektrik Piyasasında Kamu Hizmeti, (Birinci Baskı, Çakmak Yayınevi, 2010)

Feng W, Yin H and Li S, China's Renewable Energy Policy: Commitments and Challenges, (2010) 38(4), Energy Policy, 1872-1878

Gözler K, Yorum İlkeleri, Kamu Hukukçuları Platformu Anayasa Hukukunda Yorum ve Norm Somutlaşması, Türkiye Barolar Birliği, 29-30 Eylül 2012, (Birinci Bask1, TBB Yayınları, 2013)

Gözler K, İnsan Hakları Hukukuna Giriş, (Birinci Baskı, Ekin Yayıncılık, 2017)

Green A, Consumer Options For Choosing Renewable Energy, (www. judithcurry.com), https://judithcurry.com/2011/08/30/consumer-options-forchoosing-renewable-energy/ Erişim Tarihi:28.06.2021

Güveyi Ü, 1982 Anayasası Kapsamında Çevre Hakkının Karşılaştırmalı Kısa Bir Tahlili, (2018) 24(2), Marmara Üniversitesi Hukuk Fakültesi Hukuk Araştırmaları Dergisi, 633-659

Karahanoğulları O, Kamu Hizmeti, (Birinci Bask1, Turhan Kitabevi, 2015)

Lampert S, The Renewable Energy Review, Chapter 2 Austria, (2018, Law Business Research Ltd.)

Lo K, A Critical Review of China's Rapidly Developing Renewable Energy and Energy Efficiency Policies, (2014) 29, Renewable and Sustainable Energy Reviews, 508-516

Memiş E, Çevre ve Çevre İdare Hukuku, (İkinci Baskı, Filiz Kitabevi, 2015) 
IIIIIIIIII!

Mowbray A, Cases and Materials on the European Convention on Human Rights, (2nd edn, Oxford University Press, 2007)

Narin A, Su Hakkı ve Bir Müdahale Aracı Olarak Suyun Özelleştirilmesi, (2016) 7(27), TAA Dergisi, 729-755

National Renewable Energy Action Plan for the United Kingdom Article 4 of the Renewable Energy Directive 2009/28/EC (www.assets.publishing.service. gov.uk)

https://assets.publishing.service.gov.uk/government/uploads/system/uploads/ attachment_data/file/47871/25-nat-ren-energy-action-plan.pdf Erişim Tarihi: 28.06.2021

Oder Emrah B, Anayasa Yargisında Temel Hak Ve Özgürlüklerin Yorumu: Düzenleme Biçimleri, Kanıtlama Ve Somutlaştırma Sorunları-2001 Anayasa Değişiklikleri Sonrasına İlişkin Gözlemler, Kamu Hukukçuları Platformu Anayasa Hukukunda Yorum Ve Norm Somutlaşmas1, 29-30 Eylül 2012, (Birinci Bask1, TBB Yayınları, 2013)

Olgun H and Işık V, Bir İnsan Hakkı Olarak Çevre Hakkı ve Türk Hukukundaki Yeri, (2017) 3(1), Uluslararası Politik Araştırmalar Dergisi, 33-51

Ögünç O, Nükleer Çöplük mü? Temiz Enerji mi? (1999) 404, Türkiye Mühendislik Haberleri, 12-19

Özay Han İ, Günışı̆̆ında Yönetim, (Üçüncü Baskı, Filiz Kitabevi, 2017)

Özcan A, Sürdürülebilirlik Ekseninde "Yeni Çevresel Haklar Deneyimi” Ve Eko-Politik Bir Analiz: "Güneş Ve Rüzgâr Hakları, (2016) 8(1), Alternatif Politika, 34-66

Resolution Adopted By The General Assembly On 25 September 2015, Transforming Our World: The 2030 Agenda For Sustainable Development, (www.un.org)https://www.un.org/en/development/desa/population/ migration/generalassembly/docs/globalcompact/A_RES_70_1_E.pdf Erişim Tarihi:22.03.2021

Resolution Adopted By The General Assembly On 6 July 2017, 71/313. Work Of The Statistical Commission Pertaining To The 2030 Agenda For Sustainable Development. (www.undocs.org), https://undocs.org/A/RES/71/313 Erişim Tarihi: 28.06.2021

Sar C, Birleşmiş Milletler Genel Kurul Kararlarının Hukuki Değeri, (1966) 21(4), AÜSBF Dergisi, 227-274

Semiz Y, 2016, Çevre Hakkı Kavramı ve Avrupa İnsan Hakları Mahkemesi’nin Çevre Hakkına Yaklaşımı, (Yayınlanmamış Yüksek Lisans Tezi), Galatasaray Üniversitesi Sosyal Bilimler Enstitüsü 
Sommer Konuk B, Türk Hukukunda Çevre Hakkının Bireysel Başvuru Yoluyla Korunması, (2019) 4(2), Yıldırım Beyazıt Hukuk Fakültesi Dergisi, 169-188

Technology Assessment of Clean Coal Technologies for China: Environmental and Energy Efficiency Improvements for Non-Power Uses of Coal, Volume II, Esmap And Easeg Technical Paper, Esmap Publications, May 2001

Tortop N, İnsan Hakları Avrupa Mahkemesi Kararları, (2006), 62, TBB Dergisi, 449-468

Ulusoy D. A, Çevre Kirlenmesinin Oluşmasından Sonraki Aşamada Medeni Hukuk, Ceza Hukuku ve İdare Hukuku Çözümlerine Genel Bir Bakış, (1993) 43(1), AÜHF Dergisi, 125-142

What's New In Germany's Renewable Energy Act 2021(www.cleanenergywire. org) https://www.cleanenergywire.org/factsheets/whats-new-germanysrenewable-energy-act-2021 Erişim Tarihi: 28.06.2021

Yeni O, Sürdürülebilirlik Ve Sürdürülebilir Kalkınma: Bir Yazın Taramas1, (2014) 16(3), Gazi Üniversitesi İktisadi ve İdari Bilimler Fakültesi Dergisi, 181,185 
472 立 